\title{
Market Share, Market Value and Innovation in a Panel of British Manufacturing Firms
}

\author{
Richard Blundell; Rachel Griffith; John Van Reenen \\ The Review of Economic Studies, Vol. 66, No. 3. (Jul., 1999), pp. 529-554.
}

Stable URL:

http://links.jstor.org/sici?sici=0034-6527\%28199907\%2966\%3A3\%3C529\%3AMSMVAI\%3E2.0.CO\%3B2-5

The Review of Economic Studies is currently published by The Review of Economic Studies Ltd..

Your use of the JSTOR archive indicates your acceptance of JSTOR's Terms and Conditions of Use, available at http://www.jstor.org/about/terms.html. JSTOR's Terms and Conditions of Use provides, in part, that unless you have obtained prior permission, you may not download an entire issue of a journal or multiple copies of articles, and you may use content in the JSTOR archive only for your personal, non-commercial use.

Please contact the publisher regarding any further use of this work. Publisher contact information may be obtained at http://www.jstor.org/journals/resl.html.

Each copy of any part of a JSTOR transmission must contain the same copyright notice that appears on the screen or printed page of such transmission.

The JSTOR Archive is a trusted digital repository providing for long-term preservation and access to leading academic journals and scholarly literature from around the world. The Archive is supported by libraries, scholarly societies, publishers, and foundations. It is an initiative of JSTOR, a not-for-profit organization with a mission to help the scholarly community take advantage of advances in technology. For more information regarding JSTOR, please contact support@jstor.org. 


\title{
Market Share, Market Value and Innovation in a Panel of British Manufacturing Firms
}

\author{
RICHARD BLUNDELL \\ University College London and Institute for Fiscal Studies \\ RACHEL GRIFFITH \\ Institute for Fiscal Studies \\ and \\ JOHN VAN REENEN \\ University College London and Institute for Fiscal Studies
}

First version received August 1995; final version accepted July 1998 (Eds.)

\begin{abstract}
This paper examines the empirical relationship between technological innovations, market share and stock market value. New developments in the estimation of dynamic count data models are used to control for unobserved firm specific heterogeneity. We find a robust and positive effect of market share on observable headcounts of innovations and patents although increased product market competition in the industry tends to stimulate innovative activity. Furthermore, the impact of innovation on market value is larger for firms with higher market shares. We argue that our results are consistent with models where high market share firms have incentives to pre-emptively innovate.
\end{abstract}

\section{INTRODUCTION}

A recurrent question in industrial organization is whether market power encourages or inhibits firms from innovating (Schumpeter (1939)). Although a large number of empirical studies have found that dominant firms tend to have higher rates of research and development (R\&D) and innovate more (e.g. Scherer (1967)) the literature remains controversial for at least two reasons. First there is the issue of interpretation; why does market dominance enable firms to be more innovative? Second, is the correlation evidence of a causal effect of market structure on innovation or rather a statistical artifact?

In interpreting the effects of market share many authors have considered the strategic incentives arising from current and expected product market power. Gilbert and Newbery (1982), for example, argued that in an auction model of R\&D incumbent monopolists had greater incentives to search for innovations than potential entrants because total industry profits decrease when more firms share the market. This externality or "efficiency effect" is internalized by the incumbent but ignored by the entrant. Thus the monopolist will tend to innovate more and industry evolution will be characterized by persistent dominance. More recent theoretical contributions have stressed that the efficiency effect is still important in models that allow for continuing duopoly (i.e. where both firms enjoy positive market share in equilibrium), sequences of innovation and uncertainty. ${ }^{1}$

1. See Budd, Harris and Vickers (1993); Harris and Vickers (1987), for example. Beath, Katsoulacos and Ulph (1995) point out that even in the context of a simple auction model industry equilibrium may be characterized by action-reaction for markets where firm costs are similar and innovations are small. 
A traditional interpretation of the innovation-market power correlation is that failures in financial markets force firms to rely on their own supra-normal profits ${ }^{2}$ to finance the search for innovation. The availability of internal sources of funding ("deep pockets") are useful for all forms of investments, but may be particularly important for R\&D. External sources of finance may be more expensive (due, for example, to asymmetric information) and there is the risk that rival firms could acquire valuable information if a firm seeks external funding for its innovation projects (e.g. Bhattacharya and Ritter (1985)).

The more cynical line of reasoning is that the correlation of high market share and innovation is merely a statistical artifact. A priori there are as many theoretical reasons to expect a negative correlation between market power and innovation as a positive one. Reinganum (1983), for example, points to the "displacement effect" facing a monopolist who will be disinclined to win a stochastic patent race too quickly as her existing stream of rents will be displaced by an entirely new stream of rents. The challenger has no such qualms. $^{3}$

The empirical relationship between innovation and market share could be artificial for at least three reasons. First there is reverse causality: firms who innovate will grow and therefore have higher market shares. Most econometric estimators in the empirical innovation literature rule out these kind of dynamic feedback effects by assumption. A second problem relates to unobserved heterogeneity deriving, for example, from the different technological opportunities and appropriability conditions facing firms. Finally, the association could be spurious because of poor quality data. The commonly used measures of innovation are Solow residuals, R\&D expenditure and patents, yet all have serious difficulties. Solow residuals relate to diffusion and are correlated with market power by construction. ${ }^{4}$ R\&D is not reported by many firms, is an input rather than an output and is often allocated in a somewhat arbitrary fashion in firm accounts. Patents are not always implemented as innovations and many innovations are not patented. These problems are not purely econometric concerns. The results from applied work on market structure and innovation have been disturbingly sensitive to data source and estimation technique. ${ }^{5}$

In this paper it is argued that by looking at the relationship between market share and innovation together with the impact of market share on the relationship between innovations and corporate stock market value it is possible to shed light on the importance of the incentive to innovate. If the "efficiency effect" is important then one would expect a systematically higher pay-off to the innovations of high market share firms than to those of low market share firms. The main aim of this paper is to establish the relationship between innovation and market share on the one hand and stock market value and innovative activity on the other. This is carried out using firm-level panel data with a headcount innovation measure of major new technological breakthroughs. We test the robustness of the results by examining an alternative measure of innovative output (patent counts) and by examining a particular industry in greater detail (pharmaceuticals).

2. There are other arguments why ex ante market power facilitates innovation: uncertainty may be lower in concentrated markets, new innovations may be complements to old ones, and so on. Note that ex post market power is less controversially regarded as a necessary incentive to innovate in the presence of spillovers. This is why there are patent laws. See Fisher and Temin (1973) for a discussion of Schumpeter and the size-R\&D relationship.

3. In cases of drastic innovation in a one-shot patent race the efficiency effect is unimportant and the challenger will invest more. Henderson (1993) uses this fact to empirically distinguish between the two types of model.

4. See Hall (1988).

5. See the survey by Cohen and Levin (1989), for example. 
The long time series of the innovations count and market value data for each company is used to tackle some of the fundamental empirical difficulties plaguing other work. We develop an estimator in which the pre-sample information on innovations replaces the unobservable firm fixed effect. The estimation problem is one of missing data in which we have a long panel for innovations but only a short panel for the explanatory regressors. Our proposed estimator works provided the individual effects can be estimated from the pre-sample observations on innovations alone. Using the pre-sample information on innovations to define an entry innovation stock for each firm enables us to strip out many of the unobservable advantages enjoyed by different firms in order to identify the effects of market structure on a firm's likelihood to innovate. We are also able to look at how the stock market's valuation of a firm's innovation (assumed to reflect the true private economic value) varies with its innovation stock, again using a measure of the presample level of market value to control for unobservable characteristics.

The structure of the rest of the paper is as follows: Section 2 outlines a simple model of innovation, market share and market value and Section 3 details the empirical strategy and estimator. Section 4 discusses the data and presents the main results. We examine the robustness of our findings by investigating heterogeneities across industries (Section 5) and repeating the analysis using patents as an alternative measure of innovative output (Section 6). The final section offers some concluding remarks.

\section{A MODEL OF INNOVATION AND MARKET VALUE}

A key focus of interest in this paper is the estimation of an innovations equation. Typically this takes the form

$$
I_{i t}=f\left(x_{i t}, u_{i t}\right) \text { for } i=1, \ldots, N \text { and } t=1, \ldots, T \text {, }
$$

where $x_{i t}$ is a vector of firm $i$ characteristics (such as lagged market share), industry characteristics and macro-economic conditions. Unobservables are represented by the term $u_{i t}$, the properties of which are discussed in great detail in the next section where we develop our estimation strategy. Following Blundell, Griffith and Van Reenen (1995b) this relationship is derived as the outcome of a firm's optimal search rule for innovation. The search process is assumed to generate innovations in future periods. Thus the $x_{i t}$ in (2.1) will consist solely of lagged variables.

In common with other models of innovations ${ }^{6}$ the specification begins with the basic problem of a firm attempting to maximize its value $V_{i t}$ conditional upon its current information set. The value-relevant information will include current and expected future prices of various tangible and intangible capital stocks. Strategic considerations imply that product market structure will also be relevant to the current expected value of the firm. The value function is of the following form

$$
V_{i t}=\Pi\left(G_{i t}, K_{i t}, M S_{i t}, W_{t}\right)+\varphi E_{t} V_{i t+1},
$$

in which current net cash flow is $\Pi\left(G_{i t}, K_{i t}, M S_{i t}, W_{t}\right)$, depends on market share $\left(M S_{i t}\right)$, fixed capital $\left(K_{i t}\right)$ and knowledge capital $\left(G_{i t}\right)$. In (2.2) $\varphi$ is the firm's discount factor (assumed constant over time) and $E_{t}$ is the expectations operator conditioned on the firm's

6. See Reinganum (1989) for a survey. A close antecedent to the model in this paper is by Pakes (1985) who estimates a patents, R\&D and market value model. He takes a dynamic factor approach which places exclusion restrictions on the form of each equation. Unlike our paper, however, he does not attempt to examine strategic effects in the product market or explicitly model the count data properties of the patents series. 
current ( $t$-dated) information set. Other inputs are maximized out of the problem and replaced by their optimal values which depend on a vector of relative prices $W_{t}$.

It is assumed that the firm's stock of knowledge depends on a distributed lag of the current and past flows of innovative activity

$$
G_{i t}=I_{i t}+(1-\delta) G_{i t-1},
$$

where $\delta$ is the rate of stock depreciation. Economically useful knowledge depreciates because other firms can imitate innovation, personnel move and machines wear out. The model for innovation is closed by equating the marginal cost of search with the marginal benefit. Given the relationship between search and innovation, the resulting specification expresses current innovation in terms of past values of observable firm specific variables including innovation stock, market share, capital stock, industry and macro-economic conditions and unobservable firm specific heterogeneity. This places our estimating equation for innovations in the form (2.1) with $x_{i t}$ a function of $M S_{i t-1}, K_{i t-1}$, etc.

There are several interpretations of a positive coefficient on the market share variable in the innovations equation. One interpretation is that strategic considerations imply that the marginal benefit of an innovation (an additional increment to the firm's innovation stock, $G$ ) will be more valuable to a leader with high market share than a follower with low market share. Thus the leader will tend to invest more in search and therefore innovate more frequently. If this is the case we would expect innovation stocks to be more highly valued in high market share firms. We investigate this possibility by estimating two possible forms of the market value equation.

In the first approach we adopt a simple linearization of the value function based on Griliches (1981) ${ }^{7}$

$$
\frac{V_{i t}}{K_{i t}}=\kappa_{i t}\left(1+\left(\gamma_{0}+\gamma_{1} M S_{i t}\right) \frac{G_{i t}}{K_{i t}}\right) .
$$

The equilibrium value of the firm relative to the replacement value of its tangible assets $\left(V_{i t} / K_{i t}\right)$ may deviate from the expected value of unity due to the presence of intangible capital (for example, $G_{i t}$ ) or the existence of imperfect competition in the product or labour markets as captured by $\kappa_{i t}$ (so the direct effect of $M S$ will enter through $\kappa_{i t}$ ). The firms' market share, $M S_{i t}$, is the key strategic variable used to examine the Gilbert and Newbery hypothesis. If high market share firms gain a higher return from innovating then this will be reflected in a positive value of $\gamma_{1}$ in (2.4). ${ }^{8}$ Taking logs and using the approximation $\ln (1+x) \simeq x$ gives an empirical value equation of the form

$$
\ln \left(\frac{V_{i t}}{K_{i t}}\right)=\gamma_{0}\left(\frac{G}{K}\right)_{i t}+\gamma_{1}\left(M S * \frac{G}{K}\right)_{i t}+\ln \kappa_{i t} .
$$

The second approach is to estimate the impact of innovation on the change in market value. However, technological innovations are not necessarily surprise innovations. Other features of the history of innovative activity, the product market structure and the firms' financial structure, are likely to influence the probability of an innovation taking place in a predictable way. Those innovations that have been anticipated will already be capitalized into the value of the firm. For example, a firm with an historically high level of innovative

7. See also the subsequent empirical development of this literature in, for example, Jaffe (1986) and Griliches, Hall and Pakes (1991).

8. This issue of whether market share or firm size per se is the relevant variable is discussed in Section 5 . 
activity may be more likely to innovate in the future. One way around this is to look at the unexpected change in value. From (2.2) we find

$$
V_{i t}-E_{t-1} V_{i t}=\Pi_{i t}-E_{t-1} \Pi_{i t}+\varphi\left(E_{t} V_{i t+1}-E_{t-1} V_{i t+1}\right) .
$$

The term $\Pi_{i t}-E_{t-1} \Pi_{i t}$ represents the immediate "surprise" pay-off and the next term describes the unexpected revision to the discounted future value of the firm. What is important for $V_{i t}-E_{t-1} V_{i t}$ is the deviation of the actual innovation activity from its expected level. In the empirical investigation particular attention is paid to the interactions of deviations and market share.

An alternative interpretation of the coefficient on market share in the innovations equations is that it reflects the firm's ability to finance research activity. Under this view, market share enters the value function because it reduces the effective price of search faced by the firm. There is no necessary implication that firms with "deep pockets" will be rewarded with higher market value when they actually innovate. Indeed, on the margin, the value of innovations for these firms may well be lower than for firms who are more financially constrained. Nevertheless, we also investigate this alternative rationalization of the market share effect by (a) including direct measures of cash flow into our main innovation equations and (b) examining the role of total firm sales in an industry specific examination of the innovations equation.

In summary, the objective of our empirical study is to estimate the effect of market share on innovations and the effect of innovation, interacted with market share, on stock market value. The difficulty for empirical analysis is in indentifying these effects in the presence of firm specific unobservables and the feedback mechanisms that are implied by the model.

\section{THE EMPIRICAL STRATEGY FOR A PANEL OF FIRMS}

Although many of the statistical issues will be common to the estimation of the stock market value equation and to the estimation of the patents and market share relationship, we turn first to the estimation of the innovation equation. Since the actual number of recorded innovations in any period $t$ by company $i$ is a non-negative integer it is natural to model the conditional mean as a multiplicative or log-link function of explanatory factors. That is

$$
\begin{aligned}
E\left(I_{i t} \mid x_{i t}, \eta_{i}\right) & =\exp \left(x_{i t}^{\prime} \beta+\eta_{i}\right), \\
& =\mu_{i t} v_{i} \text { for } i=1, \ldots, N \text { and } t=1, \ldots, T,
\end{aligned}
$$

where $\mu_{i t}=\exp \left(x_{i t}^{\prime} \beta\right), x_{i t}$ is the vector of observable explanatory variables including the lagged values of $M S_{i t}, K_{i t}$ and $G_{i t}$ described above. These are assumed to be stationary. The term $\eta_{i}$ represents an unobservable (to the econometrician) individual firm specific effect reflecting any permanent differences in the level of innovations across firms and $v_{i}=\exp \left(\eta_{i}\right)$.

Even given the measured characteristics, some companies are likely to have permanently higher innovation levels than others due to omitted firm specific effects. These omitted effects are captured by $\eta_{i}$ in (3.1) above and are also likely to be correlated with included observable factors. Two issues arise from such a specification. The primary issue is how can $\beta$ be estimated in the presence of fixed effects $\eta_{i}$ which may be correlated with $x_{i t}$ ? The secondary issue is how should dynamics be allowed for in such a model — is it sensible to enter the lagged knowledge stock variable $G_{i t-1}$ in the exponential mean? 


\subsection{Correlated firm specific effects}

There are a number of proposals for estimating count data models which contain correlated individual effects. The standard estimator is the conditional maximum likelihood estimator (CMLE) developed by Hausman, Hall and Griliches (1984). This considers the Poisson likelihood conditional on the sum of innovations $\sum_{t=1}^{T} I_{i t}$ for each $i=1, \ldots, N$, this sum being a sufficient statistic for $\eta_{i}$ in the Poisson model. The resulting estimator is the log-link equivalent of the within groups estimator for the linear panel data model. ${ }^{9}$ It is analogous to replacing the multiplicative fixed effect $v_{i}$ in (3.1) by the ratio of means. As in the case of the within groups estimator for linear panel data models, consistency (large $N$, fixed $T$ ) of the estimator relies on the strict exogeneity of the observable explanatory factors $x_{i t}$. This is clearly ruled out by the inclusion of predetermined variables such as $G_{i t-1}$ and $M S_{i t-1}$ in our model specification.

Recently, Chamberlain (1992) and Wooldridge (1997) have suggested a quasi-differencing Generalized Method of Moments estimator GMM(qdif) that mimics the standard first differenced GMM estimator for linear panel data models with predetermined regressors. ${ }^{10}$ The quasi-differenced transformation for the model given by (3.1) may be written

$$
s_{i t}(\beta)=I_{i t}-\exp \left(\left(x_{i t}-x_{i t+1}\right)^{\prime} \beta\right) I_{i t+1} .
$$

Chamberlain (1992) and Wooldridge (1997) notice that instruments dated $t$ or before will be orthogonal to $s_{i t}(\beta)$ and therefore the moment conditions

$$
E\left(s_{i t} x_{i s}\right)=0, \quad \text { for } t \geqq s,
$$

can be used to construct a GMM estimator for $\beta$.

The transformation (3.3) can be viewed as replacing the first differenced transformation for the standard panel data model with the quasi-differenced (qdif) transformation. The precision of the GMM(qdif) estimator requires that functions of the $x_{i t}, x_{i t-1}, \ldots, x_{i 0}$ and $I_{i t-1}, I_{i t-2}, \ldots, I_{i 0}$ variables are good instruments for the difference term $\exp \left(\left(x_{i t}-x_{i t+1}\right)^{\prime} \beta\right) I_{i t+1}$. This is likely to be a particularly difficult requirement to satisfy when the $x_{i t}$ are highly persistent, as is the case for the market share variable in our empirical analysis below. As a consequence, the precision of this quasi-differenced estimator may be poor for application to the type of data used in this paper. This motivates our search for alternative methods of controlling for correlated fixed effects in count data models with predetermined regressors. The issue of weak instruments for this quasidifferenced GMM estimator is further investigated below in a small Monte Carlo simulation.

\subsection{An alternative estimator}

One interpretation of the fixed effect in the innovation equation is that it reflects the "entry level innovation knowledge stock" of each firm. That is the stock of past innovations at the beginning of the panel sample. This interpretation is particularly attractive for our empirical implementation since, for each firm, we have a long pre-sample history of ; the innovations count. This can be used to construct an entry stock measure of the firm's permanent level of innovations.

9. See Blundell, Griffith and Windmeijer (1996), for example.

10. See Arellano and Bond (1991) for a detailed discussion of the standard GMM estimator for the linear dynamic panel data model. 
To derive this new estimator based on the pre-sample mean of the innovation series we first write the stochastic specification of the model for innovations as

$$
I_{i t}=\exp \left[x_{i t}^{\prime} \beta+\eta_{i}\right]+v_{i t}
$$

where $v_{i t}$ is assumed to have mean zero conditional on $x_{i t}$ and $\eta_{i}$ and finite variance. Suppose the pre-sample size is $T P$, and consider taking averages of (3.5) over the presample observations $t=0,-1,-2, \ldots,-T P$ :

$$
\sum_{t=0}^{-T P} T P^{-1} I_{i t}=\sum_{t=0}^{-T P} T P^{-1} \exp \left[x_{i t}^{\prime} \beta+\eta_{i}\right]+\sum_{t=0}^{-T P} T P^{-1} v_{i t} .
$$

Taking probability limits as the pre-sample size $T P \rightarrow \infty$ we have

$$
\ln \left(\operatorname{plim}_{T P \rightarrow \infty} \sum_{t=0}^{-T P} T P^{-1} I_{i t}\right)=\ln \left(\operatorname{plim}_{T P \rightarrow \infty} \sum_{t=0}^{-T P} T P^{-1} \exp \left[x_{i t}^{\prime} \beta\right]\right)+\eta_{i} .
$$

Now suppose that the stationary distribution of $x_{i t}$ for each $i$ is multivariate normal with mean $\phi \eta_{i}$ and variance covariance matrix $\Omega_{x}$, suppose also that we define $m_{i o} \equiv \operatorname{plim}_{T P \rightarrow \infty} \sum_{t=0}^{-T P} T P^{-1} I_{i t}$ then

$$
\ln m_{i o}=\beta^{\prime} \phi \eta_{i}+\beta^{\prime} \Omega_{x} \beta / 2+\eta_{i}
$$

or simply

$$
\eta_{i}=\vartheta+\varsigma \ln m_{i o}
$$

Substituting for $\eta_{i}$ the log link model (3.1) now becomes

$$
E\left(I_{i t} \mid x_{i t}, \eta_{i}\right)=\exp \left(x_{i t}^{\prime} \beta+\vartheta+\varsigma \ln m_{i o}\right),
$$

where $\vartheta$ simply adjusts the constant term in $\beta$. The multivariate normal assumption on $x_{i t}$ can clearly be generalized to other distributions by adding terms in the higher moments to (3.6). All we require is that these moments be constant across $i$ and linear in $\eta_{i}$.

In estimation we suggest using the pre-sample mean of innovations for each firm $\bar{I}_{i 0}=\sum_{t=0}^{-T P} T P^{-1} I_{i t}$, to replace $m_{i o}$ in (3.7). With the assumptions on $v_{i t}$ and $x_{i t}$ in place any moment estimator based on (3.7) with $\bar{I}_{i 0}$ replacing $m_{i o}$ will be consistent for large $T P$.

The estimation problem can be interpreted as one of missing data in which we have a "long $T$ " panel for $I_{i t}$ but a "short $T$ " panel for $x_{i t}$. The proposed estimator works provided the individual effects can be estimated from the history of observations on $I$ alone. The idea of using past observations to remove the bias from unobserved heterogeneity has its antecedent in the work of Chamberlain (1982). In particular he considered the use of long lags in regressors. In contrast, our suggested estimator is based on past values of the dependent variable and uses values dated before the estimation sample. This has a distinct advantage in the case of weakly exogenous (pre-determined) regressors since the measure of the fixed effect is based exclusively on pre-sample information. As a result it will be uncorrelated with any subsequent shocks to the innovation equation. Using the pre-sample mean of the innovations as an estimator for unobservable firm differences in innovations is likely to behave better than the GMM(qdif) estimator for the case of persistent regressors. This is confirmed in our Monte Carlo analysis and is also reflected in the performance of the two estimators in the application.

This approach requires that all the permanent effects are captured through the entry innovation stock $\bar{I}_{i 0}$. However, it may well be that the $x_{i t}$ process has additional individual effects. Among other things this may reflect permanent differences in the (mis-)measurement of market share across firms. As the pre-sample values of the majority of the $x_{i t}$ 
variables are unavailable, in our empirical analysis as a robustness check we consider a further alternative estimator that includes taking deviations from the initial values $x_{i 0}$. This is analogous to

$$
\begin{aligned}
I_{i t} & =\left(\exp \left(x_{i t}-x_{i 0}\right)^{\prime} \beta\right) \bar{I}_{i 0}+u_{i t}^{\dagger}, \\
& =\exp \left(x_{i t}^{\prime} \beta\right) \frac{\bar{I}_{i 0}}{\mu_{i 0}}+u_{i t}^{\dagger},
\end{aligned}
$$

where $\mu_{i 0}=\exp \left(x_{i 0}^{\prime} \beta\right)$ and $E\left(u_{i t}^{\dagger} \mid x_{i t}, \bar{I}_{i 0}, \mu_{i 0}\right)=0$. Here that ratio $\bar{I}_{i 0} / \mu_{i 0}$ is being used to approximate the fixed effect $v_{i}$ in (3.2).

As noted above the consistency of the pre-sample mean estimator requires a long pre-sample history and will not hold exactly for finite pre-sample time periods. However, evidence from the Monte Carlo simulations below suggests that where the $x_{i t}$ display slow movement over time, the estimators based on approximating the multiplicative fixed effect using pre-sample information can perform well, even in cases where the quasi-differenced GMM estimator behaves poorly.

\subsection{Incorporating lagged dependent variables}

Next we turn to the introduction of dynamics and the specification of the lagged knowledge stock variable $G_{i t-1}$. From (2.3) $G_{i t-1}$ can be seen to be a simple distributed lag of past innovations

$$
G_{i t-1}=d(L) I_{i t-1}
$$

where $d(L)=1+(1-\delta) L+(1-\delta)^{2} L^{2}+\cdots$ and $L$ is the lag operator. We consider two alternative dynamic specifications. The first is the linear feedback model (LFM) which takes the form

$$
E\left(I_{i t} \mid G_{i t-1}, x_{i t}, \eta_{i}\right)=\theta G_{i t-1}+\exp \left(x_{i t}^{\prime} \beta+\eta_{i}\right),
$$

with $\theta>0$. This model is based on the integer-valued autoregressive (INAR) process. ${ }^{11}$ The stability of this model can be assessed directly from the AR coefficient. The (partial) long-run effect, assuming stationarity and ignoring any feedback through the $x_{i t}$, is given by $\beta E\left(I_{i t}\right)$ and the short-run effect is given by $\beta[1-(\theta /(1-\delta))] E\left(I_{i t}\right)$.

As an alternative dynamic specification we consider the multiplicative feedback model (MFM) given by

$$
\begin{aligned}
E\left(I_{i t} \mid G_{i t-1}, x_{i t}, \eta_{i}\right) & =\exp \left(\alpha D_{i t} \ln G_{i t-1}+\gamma D_{i t}+x_{i t}^{\prime} \beta+\eta_{i}\right) \\
& =\left(G_{i t-1}^{D_{i t}}\right)^{\alpha}\left(D_{i t}\right)^{\gamma} \exp \left(x_{i t}^{\prime} \beta\right) v_{i},
\end{aligned}
$$

in which $D_{i t}$ is a binary indicator which is unity when $G_{i t-1}>0$. In this model the nonlinear dynamic makes it difficult to judge the stability properties of the model and the potentially important feedback parameter $\alpha$, is sensitive to large innovation counts. The different parameterization between the two models implies that, in the comparison to the LFM, $\beta E\left(I_{i t}\right)$ in the MFM model measures the short-run impact of a change in $x_{i t}$. In the application below both models are found to yield similar estimates for the main parameters of interest, although a non-nested comparison between the two specifications suggests a preference for the LFM specification (3.11). The quasi-differenced and pre-sample adjusted estimators can be easily adapted for each of these dynamic specifications.

11. See Blundell, Griffith and Windmeijer (1999) and McKenzie (1988), for example. 


\subsection{A Monte Carlo comparison}

Before turning to our application, we present a small Monte Carlo examination of the comparative finite sample properties of the quasi-differenced and pre-sample estimators for the dynamic count data model. ${ }^{12}$ The design is chosen to closely match the sample properties of the innovation and market share series in the company data set used in the application below.

$$
\begin{gathered}
x_{i t}=\rho x_{i t-1}+(1-\rho) \zeta \eta_{i}+\sqrt{1-\rho^{2} u_{i t}}, \\
u_{i t} \sim N\left[0, \sigma_{u}^{2}\right],
\end{gathered}
$$

with $\rho=0.95$ and $\sigma_{u}^{2}=0.015$. The highly autoregressive property of the $x_{i t}$ series is generated to mimic the market share series. For example, using the Arellano and Bover (1995) GMM estimator, we find a first-order autocorrelation coefficient (standard error) of 0.944 $(0 \cdot 117)$ on market share in our data.

TABLE 3.1

Monte Carlo simulation results

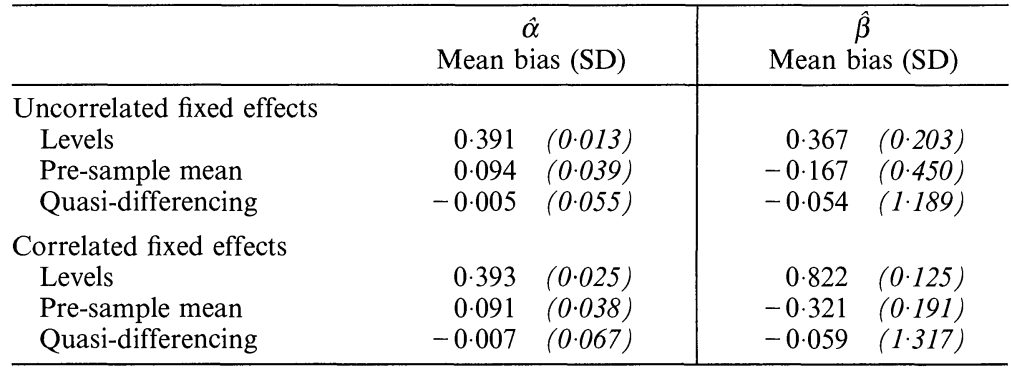

We consider the case of uncorrelated fixed effects $(\zeta=0)$ and correlated fixed effects $(\zeta=0.01)$. The count process is simulated from a Poisson with conditional mean specification

$$
E\left(y_{i t} \mid G_{i t-1}, x_{i t}, \eta_{i}\right)=\alpha G_{i t-1}+\exp \left(\beta x_{i t}+\eta_{i}\right),
$$

with the fixed effect given by

$$
\eta_{i} \sim N\left[0, \sigma_{\eta}^{2}\right]
$$

and the stock variable generated according to

$$
G_{i t}=y_{i t}+(1-\delta) G_{i t-1},
$$

where $\alpha=0.195, \beta=1 \cdot 0, \delta=0.3$ and $\sigma_{\eta}^{2}=0 \cdot 75$. The sample size is $N=350$ and the full sample period is forty years, ${ }^{13}$ we use 29 years for the pre-sample period for $y_{i t}$ and 11 years as the sample estimation period.

The properties of three estimators are considered: (i) a GMM estimator on the levels model assuming no fixed effects, (ii) the pre-sample mean estimator (3.8) and (iii) a quasidifferenced GMM estimator. The mean bias and standard deviation are presented in Table 3.1 for 1000 replications of $x$ and $y$. The levels GMM estimator shows the expected upward bias when correlated fixed effects are present. Although the quasi-differencing has a smaller bias it has, as expected for the case of highly autoregressive regressors,

12. A general set of Monte Carlo simulations for dynamic count data models is given in Blundell, Griffith and Windmeijer (1999).

13. We calculate 20 additional initial periods to insure that the results are invariant to starting values. 
a very large variance and therefore RMSE. The mean scaling estimator, on the other hand, exhibits some downward bias but appears fairly precise.

\subsection{A statistical model for market value}

To implement the estimation of the value equation (2.5) we need to provide a specification of the stochastic term $\kappa_{i t}$. This is modelled as using the following multiplicative specification in observable and unobservable factors

$$
\kappa_{i t}=\exp \left(z_{i t}^{\prime} \beta+v_{i}+u_{i t}\right),
$$

where $z_{i t}$ may include predetermined (weakly exogenous) factors such as lagged values of $G_{i t}$ and $K_{i t}, v_{i}$ are permanent unobservable components and $u_{i t}$ represent transitory shocks. Given $v_{i}$, the error terms $u_{i t}$ will be assumed to be serially independent.

As in our discussion of controlling for firm specific effects in the innovation equation, the firm specific effect $v_{i}$ in (3.15) can be dealt with in a number of ways. Our first approach measures individual permanent effects using pre-sample information on the stock market value and capital stock. Just as in the discussion of the pre-sample mean estimator for the innovation equation, this exploits the availability of a long history for $V_{i t}$ in the data set. The linearity of the relationship means that a form like (3.7) can be derived without placing restrictions on the second order moments of the explanatory variables. Although for the tangible capital stock there is a much shorter pre-sample history available, the slow evolution of this variable means that the permanent level can be pinned down with relatively few observations. Given this measure of $v_{i}, \beta$ can be estimated consistently using a moment estimator based on the covariance restriction $E\left(u_{i t} z_{i t}\right)=0$.

As an alternative approach to dealing with the presence of fixed effects, a moment estimator for the levels equation is used which controls for individual effects following the Arellano and Bover (1995) suggestion. In this method the levels equation (2.5) is estimated using instruments that are the lagged differences of the explanatory variables. Blundell and Bond (1998) show this to be a particularly attractive alternative to the standard first differenced GMM estimator for linear dynamic panel data models in which the explanatory variables are highly autoregressive.

Finally, we examine the relationship between technological innovation and firm performance by considering the impact of a "surprise" innovations on the growth of market value. The innovation "surprise" is constructed as the difference between the predicted number of innovations as estimated from the preferred model (3.11) and the realized outcome. Thus we construct the "innovation in innovation". Only the unexpected component should have significant effect on the growth in the firm's market value according to equation (2.6). The aim will be to see whether the effect of an innovation varies systematically with the market share of the firm.

It is likely that this last estimator will be particularly sensitive to misspecification. Transforming the variables into growth rates clearly remove firm specific effects but presents severe practical difficulties for at least two reasons. First, as noticed by other researchers in the patent valuation literature (e.g. Griliches (1990)), differences in the stock market valuation contain a large noise component. Looking for the effect of innovațion is like searching for a needle in a haystack. This is primarily due to the problem of dating. We are considering a large event window-an entire year-when there were many more value-relevant events than innovation. Additionally the calendar year and the accounting year often do not coincide. Secondly, and more deeply, there is the problem that information leaks out before the event of an innovation so the market has already partly 
discounted its value. Some of this information is in our data and we can try and predict innovations. Some of it is clearly unobserved. Both of these factors will tend to make it difficult to reject the null that innovations have no effect on the revisions in firm market value.

\section{RESULTS}

\subsection{Data description}

This model is applied to firm level data including information from company accounts (Datastream), share price information, a count of innovations from the Science Policy Research Unit (SPRU) and a count of patents registered at the U.S. Patent Office. Industry level information on imports, concentration and union density is also utilized. The final sample contains 3551 observations from 340 manufacturing firms listed on the London International Stock Exchange for which at least nine continuous years of data exist between 1972 and 1982 (see Data Appendix for details).

Innovation is a count of "technologically significant and commercially important" innovations commercialized by the firm. Innovation stock, $G_{i t}$, is measured as in equation (2.3). ${ }^{14}$ As described in Section 3 the measure of the individual specific fixed effect is the mean pre-sample innovation count. This is supplemented with a dummy variable equal to one if the firm ever innovated in the pre-sample period. This captures the fact that firms who never innovate may be qualitatively different from those who innovated at least once. $^{15}$

Market value is measured by the product of the company's outstanding shares and the price of these shares on the last day of the year, plus outstanding debt. This was chosen to get the best match possible between the innovations dating and the market value of the firm. ${ }^{16}$ Tangible capital stock is the replacement value of a firm's capital stock. Concentration is the proportion of sales in a firm's industry that is accounted for by the five largest domestic firms, and import penetration is the value of imports over home demand in the firm's industry. Union density is the proportion of workers who are members of a trade union in the firm's industry. The user and producer innovation stock variables are constructed as in equation (2.3) by using the count of innovations that were used and produced in the firm's industry. These pick up rivalry and spill-over effects. Market share is the company's sales divided by total industry sales. A firm's industry was defined as its principal operating industry at the 3 digit level. It would be preferable to construct a measure of market share at a more disaggregated level, but this information is not available from company accounts. Controlling for fixed effects removes some of the measurement error in MS that is permanent over time. The capital stock of the firm is a control for size, but it may be that some of the effect attributed to MS reflects from size. This is examined in Section 5 where we focus on a particular industry and compare sales with market share. Descriptive statistics and sources of the variables are shown in Appendix A.

14. A depreciation rate of $30 \%$ was used, although we report experiments with alternative depreciation rates (which made little difference to the qualitative results reported below).

15. The initial stock of innovations is included in its logged form in estimation. For firms that have zero pre-sample information we use the log of an arbitrarily small constant and let this dummy variable estimate its level. results.

16. An average of the price in the last three months of the year was also used with little effect on the 


\subsection{Innovation equation results}

Table 4.1 shows the estimates of the innovation-market share relationship. In each case the log-link model (3.1) is estimated with each column relating to different specifications regarding permanent effects and dynamic feedback. The numbers in italics are standard errors and allow for general heteroskedasticity across individuals and autocorrelation and over time.

In column (1) estimates of the model without dynamics or any control for fixed effects are presented. There is persistent serial correlation ${ }^{17}$ which could indicate the presence of permanent heterogeneity. From the discussion of the various alternative hypotheses regarding the determination of firm's innovative behaviour, it is the signs and magnitudes of the coefficients that are of direct interest. Market share enters positively and is quite precisely determined. Industry concentration is negatively associated with the number of innovations. Import penetration, possibly capturing a trade effect, is positively associated with innovation. Although it is the firms with larger market share that are more likely to innovate, the overall impact of competition on the aggregate number of industry innovations is positive. Firms appear to innovate less in downturns as indicated by the negative effects of the recession dummies of 1973-1974 and 1980-1982. This procyclical innovative activity may be driven by the desire to capture rents when demand is buoyant. The industry knowledge variables enter with opposite signs. $G$-User is the stronger and positive effect which could reflect either complementarities in the production of innovations or rivalry effects.

In columns (2)-(5) measures of the mean pre-sample count of innovations are included to control for permanent differences in firms' propensity to innovate. Evidence that this controls for firm specific effects is given by the reduction in persistent serial correlation. ${ }^{18}$ Dynamics are included in column (2) and modelled multiplicatively, as given by the multiplicative feedback model (MFM) shown in equation (3.12). An alternative dynamic specification, the linear feedback model (LFM), given by equation (3.11), is considered in columns (3)-(6). The interpretation of the coefficients is not the same across these alternative dynamic specifications (see discussion in Section 3.3). The MFM model shown in column (2) implies a short-run impact of market share on innovation of 0.15 while the short-run impact implied by the LFM specification in column (3) is $0 \cdot 16$. The elasticity of innovation with respect to market share evaluated at the mean market share using the MFM model ${ }^{19}$ is $0 \cdot 08$, while under the $\mathrm{LFM}^{20}$ it is $0 \cdot 10$. The market share result is robust to these alternative dynamic specifications.

A comparison of the competing non-nested specifications can be made using the $\mathbf{J}$ statistic. ${ }^{21}$ The test regression of the model in column (2) of Table 4.1 vs. column (3) gives

$$
y_{i t}=\underset{(0.133)}{-0.205} \hat{y}_{i t}^{(2)}+\underset{(0.132)}{1.195} \hat{y}_{i t}^{(3)} \text {, }
$$

indicating that the LFM is strongly preferred.

As a check on the robustness of our results we consider transforming the firm level variables into "long" differences from their initial pre-sample values (see equation (3.8)). This leads to the expected loss of precision, but did not alter the conclusions based on the

17. See Blundell, Griffith and Van Reenen (1995a) for a more detailed discussion of this model.

18. The residual covariance matrices (not shown here) show a dramatic fall in the degree of autocorrelation.

19. This is $(\beta /(1-\alpha)) \ddot{X}=(1 \cdot 34 /(1-0 \cdot 33)) 0 \cdot 04=0 \cdot 08$.

20. This is $\beta \bar{X}=2 \cdot 5 * 0 \cdot 04$.

21. This is the Davidson-MacKinnon non-nested test between the two models. The test is performed by calculating the mean function of the alternate models, $\hat{y}_{i t}$, and then running the OLS regression $y_{i t}=\delta \hat{y}_{i t}^{(1)}+(1-\delta) \hat{y}_{i t}^{(2)}$. The two null hypotheses to be tested are $H_{0}: \delta=0$ and $H_{0}: \delta=1$. 
TABLE 4.1

The Innovation Equation Estimates

\begin{tabular}{|c|c|c|c|c|c|c|}
\hline & (1) & (2) & (3) & (4) & (5) & (6) \\
\hline$G_{-1}$ & - & - & $\begin{array}{l}0 \cdot 123 \\
0 \cdot 052\end{array}$ & $\begin{array}{l}0 \cdot 122 \\
0 \cdot 052\end{array}$ & $\begin{array}{l}0.156 \\
0.037\end{array}$ & $\begin{array}{r}-0.086 \\
0.352\end{array}$ \\
\hline $\ln \left(G_{-1}\right)$ & - & $\begin{array}{l}0.331 \\
0.081\end{array}$ & - & - & - & - \\
\hline$G_{-1}$ dum & - & $\begin{array}{l}0 \cdot 540 \\
0 \cdot 750\end{array}$ & - & - & - & - \\
\hline$M S_{-1}$ & $\begin{array}{l}4.318 \\
0.988\end{array}$ & $\begin{array}{l}1.336 \\
0.451\end{array}$ & $\begin{array}{l}2.534 \\
0.713\end{array}$ & $\begin{array}{l}2.568 \\
0.699\end{array}$ & $\begin{array}{l}3 \cdot 207 \\
1.028\end{array}$ & $\begin{array}{l}3.739 \\
3.278\end{array}$ \\
\hline Conc $_{-1}$ & $\begin{array}{r}-1.967 \\
0.936\end{array}$ & $\begin{array}{r}-1.498 \\
0.676\end{array}$ & $\begin{array}{r}-2.198 \\
0.976\end{array}$ & $\begin{array}{r}-2.190 \\
0.896\end{array}$ & $\begin{array}{r}-1.759 \\
1.135\end{array}$ & $\begin{array}{r}-6.499 \\
11 \cdot 111\end{array}$ \\
\hline Imports $_{-1}$ & $\begin{array}{l}1.214 \\
0.925\end{array}$ & $\begin{array}{l}0.987 \\
0.806\end{array}$ & $\begin{array}{l}1 \cdot 258 \\
1 \cdot 118\end{array}$ & $\begin{array}{l}1 \cdot 316 \\
1 \cdot 312\end{array}$ & $\begin{array}{l}1.597 \\
1.254\end{array}$ & $\begin{array}{l}0.841 \\
2.941\end{array}$ \\
\hline$K_{-1}$ & $\begin{array}{l}0.894 \\
0 \cdot 228\end{array}$ & $\begin{array}{l}0 \cdot 124 \\
0 \cdot 122\end{array}$ & $\begin{array}{l}0 \cdot 208 \\
0 \cdot 181\end{array}$ & $\begin{array}{l}0.200 \\
0 \cdot 191\end{array}$ & $\begin{array}{l}0 \cdot 060 \\
0 \cdot 244\end{array}$ & $\begin{array}{l}0.036 \\
0.494\end{array}$ \\
\hline $\mathrm{Cash}_{-1}$ & - & - & - & $\begin{array}{r}-0.207 \\
0.534\end{array}$ & - & - \\
\hline$G$-Prod $_{-1}$ & $\begin{array}{r}-0.282 \\
0.567\end{array}$ & $\begin{array}{r}-0.466 \\
0.384\end{array}$ & $\begin{array}{r}-0.422 \\
0.547\end{array}$ & $\begin{array}{r}-0.416 \\
0.548\end{array}$ & $\begin{array}{r}-0.133 \\
0.629\end{array}$ & $\begin{array}{r}-0.768 \\
3.612\end{array}$ \\
\hline$G$-User ${ }_{-1}$ & $\begin{array}{l}4.917 \\
1.740\end{array}$ & $\begin{array}{l}2.562 \\
1 \cdot 381\end{array}$ & $\begin{array}{l}3.278 \\
1.900\end{array}$ & $\begin{array}{l}3.288 \\
1.920\end{array}$ & $\begin{array}{l}2.299 \\
2 \cdot 174\end{array}$ & $\begin{array}{l}1.662 \\
2.596\end{array}$ \\
\hline $\ln \left(G_{0}\right)$ & - & $\begin{array}{l}0.452 \\
0 \cdot 106\end{array}$ & $\begin{array}{l}0.838 \\
0 \cdot 114\end{array}$ & $\begin{array}{l}0.829 \\
0 \cdot 114\end{array}$ & $\begin{array}{l}0 \cdot 862 \\
0 \cdot 129\end{array}$ & - \\
\hline$G_{0}$ dum & - & $\begin{array}{l}0.696 \\
0.793\end{array}$ & $\begin{array}{l}1.825 \\
0.739\end{array}$ & $\begin{array}{l}1.660 \\
0.750\end{array}$ & $\begin{array}{l}2 \cdot 062 \\
0 \cdot 862\end{array}$ & - \\
\hline 1973-1974 & $\begin{array}{r}-0.300 \\
0.153\end{array}$ & $\begin{array}{r}-0.432 \\
0.162\end{array}$ & $\begin{array}{r}-0.957 \\
0.494\end{array}$ & $\begin{array}{r}-0.926 \\
0.478\end{array}$ & - & - \\
\hline 1980-1982 & $\begin{array}{r}-0.993 \\
0.209\end{array}$ & $\begin{array}{r}-0.676 \\
0.252\end{array}$ & $\begin{array}{r}-0.934 \\
0.616\end{array}$ & $\begin{array}{r}-0.959 \\
0.614\end{array}$ & - & - \\
\hline Constant & $\begin{array}{r}-2.956 \\
0.588 \\
\end{array}$ & $\begin{array}{r}-0.195 \\
0.408\end{array}$ & $\begin{array}{r}-0.327 \\
0.689\end{array}$ & $\begin{array}{r}-0.326 \\
0.698 \\
\end{array}$ & - & - \\
\hline $\begin{array}{l}\text { Time dummies } \\
\text { Observations } \\
\text { Time period } \\
v_{1} \\
v_{2}\end{array}$ & $\begin{array}{c}\text { no } \\
3511 \\
1972-1982 \\
1.210 \\
2.980\end{array}$ & $\begin{array}{c}\text { no } \\
3511 \\
1972-1982 \\
-0 \cdot 270 \\
0 \cdot 271\end{array}$ & $\begin{array}{c}\text { no } \\
3511 \\
1972-1982 \\
-0.474 \\
-0.573\end{array}$ & $\begin{array}{c}\text { no } \\
3511 \\
1972-1982 \\
-0.472 \\
-0.572\end{array}$ & $\begin{array}{c}\text { yes } \\
3511 \\
1972-1982 \\
-0.059 \\
-0.913\end{array}$ & $\begin{array}{c}\text { yes } \\
3211 \\
1972-1981\end{array}$ \\
\hline
\end{tabular}

Notes. Standard errors are in italics and allow for general heteroskedasticity and autocorrelation. Dummy variables for GEC and ICI are included in all columns except (6). In columns (2)-(5) instruments include a single lag of each variable and the initial value of firm level variables $(M S$ and $K) . v_{1}$ and $v_{2}$ are the standard serial correlation statistics from Arellano and Bond $(1991)$ distributed $N(0,1)$ under the null of no serial correlation. In column (6) instruments are lags of all variables.

entry stock specifications. If anything the market share effects are strengthened. Using $\left(M S_{i t}-M S_{i 71}\right)$ and $\left(K_{i t}-K_{i 71}\right)$ in place of their level equivalents in column (3) yields a coefficient (standard error) of 7.4 (3.2) on the market share term. Allowing the coefficients on the current and initial level to vary gives estimates of 5.2 (2.3) on the coefficient (standard error) on $M S_{i t}$ and -2.4 (2.9) on the coefficient (standard error) on $M S_{i 71}$.

As an additional test of the specification, in column (4) of Table 4.1 a measure of firms' cash flow is included. It is negative, insignificant and does not change the market share coefficient. Column (5) includes a full set of time dummies instead of the recession dummies. Although the restriction to the two dummies is not statistically rejected (the 
$\chi^{2}(8)$ Wald test statistic has a value 2.952), it is reassuring to observe that (although slightly more imprecise) the main results are robust to this experiment.

Finally, in order to check that the initial innovation stock variable $G_{i 0}$ is sufficient to account for permanent differences across firms in column (6) we implement the quasidifferenced GMM estimator defined by (3.3). As shown in the Monte Carlo simulations in Table 3.1 this estimator has low bias but very high RMSE when the time-series structure of the regressors is close to random walk. In this case it is difficult to find reliable instruments. This is particularly the case for the market share variable which is highly persistent (we noted an autocorrelation coefficient of 0.944 earlier in the discussion). Unsurprisingly, the standard errors are very large in column (6) which makes inference hazardous. Nevertheless, the market share coefficient is positive and slightly larger than that of the previous column, but still lower than the model without controls for fixed effects. This is consistent with the Monte Carlo evidence presented in Section 3.4 which suggests that, if anything, the pre-sample mean estimator underestimates the impact of market share on innovation to a greater extent than GMM(qdif). All the other coefficients in the quasi-differenced estimator are signed the same as the mean scaling estimator with the exception of lagged innovation stock (although the standard error is huge). The pattern of coefficients is again in line with the Monte Carlo results which suggested some downwards finite sample bias on the lag coefficient in the quasi-differenced estimator and some upwards bias for the pre-sample mean scaling estimator.

The results presented in Table 4.1 suggest that high markets share firms have a higher expected number of innovations, even when unobserved heterogeneity is controlled for through the use of pre-entry innovation stocks. They also indicate that market share does not simply represent the greater liquidity of high market share firms (as proxied by cash flow). One alternative explanation for the market share effect is that it represents preemption by domimant firms. To examine this hypothesis we turn to the stock market value equation.

\subsection{Market value results}

The aim in this section is to estimate the relationship between the firm's stock of innovations (normalized on physical capital) and its stock market value. The estimation results are presented in Table 4.2. All current dated firm level variables are instrumented. In columns (1) $-(5)$ they are instrumented with their own $(t-1)$ lags. In columns (6) and (7) longer lags are used as instruments as the panel progresses through time and GMM is used for estimation. Turning first to column (1) we estimate a baseline model without interactions between market share and innovation stock. In this specification innovation stocks, $G_{i t}$, appear to be valued significantly by the stock market, as expected. A major concern is that there are permanent unobserved differences in the value of firms that may be correlated with innovation. To control for these, the approach described in Section 3 is taken in column (2) and variables capturing pre-sample averages of firms' stock market value $^{22}$ and innovation stocks are included. The initial stocks of value, physical capital, market share and inventories are also included. The innovation stock variable remains

22. The pre-sample market value is the market value of equity only. This is available from the mid 1950 s. The alternative is to use market value of equity plus debt (which are the dependent variables). Unfortunately, debt is available only from 1968. Using this alternative measure of the pre-ample average does not alter the results. The interaction term has a coefficient (standard error) of 175.9 (38.59), the linear $G / K$ term is 0.978 $(0.890)$ and the pre-sample average is $0.099(0.014)$. 
TABLE 4.2

Market value in levels

\begin{tabular}{|c|c|c|c|c|c|c|c|}
\hline & $\begin{array}{c}\ln (V) \\
(1)\end{array}$ & $\begin{array}{l}\ln (V) \\
(2)\end{array}$ & $\begin{array}{c}\ln (V) \\
(3)\end{array}$ & $\begin{array}{c}\ln (V) \\
(4)\end{array}$ & $\begin{array}{c}\ln (V / K) \\
(5)\end{array}$ & $\begin{array}{c}\ln (V / K) \\
(6)\end{array}$ & $\begin{array}{c}\ln (V / K) \\
(7)\end{array}$ \\
\hline $\ln (K)$ & $\begin{array}{l}0.688 \\
0.016\end{array}$ & $\begin{array}{l}1.098 \\
0.061\end{array}$ & $\begin{array}{l}1.095 \\
0.061\end{array}$ & $\begin{array}{l}1.088 \\
0.058\end{array}$ & - & - & - \\
\hline$G / K$ & $\begin{array}{l}1.928 \\
0.933\end{array}$ & $\begin{array}{l}2.064 \\
0.970\end{array}$ & $\begin{array}{l}1.421 \\
0.947\end{array}$ & $\begin{array}{l}1.615 \\
0.923\end{array}$ & $\begin{array}{l}1.582 \\
0.921\end{array}$ & $\begin{array}{l}1 \cdot 840 \\
0 \cdot 885\end{array}$ & $\begin{array}{l}4 \cdot 370 \\
1 \cdot 852\end{array}$ \\
\hline$M S$ & $\begin{array}{l}0 \cdot 600 \\
0 \cdot 144\end{array}$ & $\begin{array}{l}0 \cdot 341 \\
0 \cdot 380\end{array}$ & $\begin{array}{l}0 \cdot 075 \\
0 \cdot 350\end{array}$ & $\begin{array}{l}0.007 \\
0 \cdot 329\end{array}$ & $\begin{array}{l}0.068 \\
0 \cdot 327\end{array}$ & $\begin{array}{l}0 \cdot 277 \\
0 \cdot 327\end{array}$ & $\begin{array}{c}-0.001 \\
0.671\end{array}$ \\
\hline$M S *(G / K)^{a}$ & - & - & $\begin{array}{l}1.588 \\
0.404\end{array}$ & $\begin{array}{l}1.733 \\
0.402\end{array}$ & $\begin{array}{l}1.745 \\
0.403\end{array}$ & $\begin{array}{l}1.767 \\
0 \cdot 376\end{array}$ & $\begin{array}{l}1.715 \\
0.952\end{array}$ \\
\hline Conc & - & - & - & $\begin{array}{l}0.374 \\
0.082\end{array}$ & $\begin{array}{l}0.379 \\
0.082\end{array}$ & $\begin{array}{l}0.385 \\
0.082\end{array}$ & $\begin{array}{l}0 \cdot 441 \\
0 \cdot 211\end{array}$ \\
\hline Imports & - & - & - & $\begin{array}{r}-0.316 \\
0.099\end{array}$ & $\begin{array}{r}-0.319 \\
0.099\end{array}$ & $\begin{array}{r}-0.315 \\
0.099\end{array}$ & $\begin{array}{r}-0.321 \\
0.265\end{array}$ \\
\hline Union & - & - & - & $\begin{array}{r}-0.260 \\
0.113\end{array}$ & $\begin{array}{r}-0.259 \\
0 \cdot 113\end{array}$ & $\begin{array}{c}-0.264 \\
0 \cdot 113\end{array}$ & $\begin{array}{c}-0.267 \\
0 \cdot 271\end{array}$ \\
\hline$G$-User & - & - & - & $\begin{array}{r}-0.345 \\
0.222\end{array}$ & $\begin{array}{r}-0.331 \\
0.223\end{array}$ & $\begin{array}{r}-0 \cdot 357 \\
0 \cdot 223\end{array}$ & $\begin{array}{r}-0.543 \\
0.500\end{array}$ \\
\hline$G$-Prod & - & - & - & $\begin{array}{l}0.255 \\
0.062\end{array}$ & $\begin{array}{l}0.252 \\
0.062\end{array}$ & $\begin{array}{l}0.260 \\
0.062\end{array}$ & $\begin{array}{l}0.331 \\
0 \cdot 136\end{array}$ \\
\hline $\ln \left(V_{0}\right)$ & - & $\begin{array}{l}0.151 \\
0.014 \\
0.145 \\
0.040\end{array}$ & $\begin{array}{l}0.152 \\
0.014 \\
0.004 \\
0.049\end{array}$ & $\begin{array}{r}0.141 \\
0.014 \\
-0.030 \\
0.056\end{array}$ & $\begin{array}{r}0 \cdot 141 \\
0 \cdot 014 \\
-0.029 \\
0.048\end{array}$ & $\begin{array}{r}0.142 \\
0.014 \\
-0.030 \\
0.047\end{array}$ & $\begin{array}{r}0.144 \\
0.036 \\
-0.026 \\
0.120\end{array}$ \\
\hline$G_{0} \mathrm{dum}$ & - & $\begin{array}{r}-0.182 \\
0.029\end{array}$ & $\begin{array}{r}-0.184 \\
0.028\end{array}$ & $\begin{array}{r}-0.181 \\
0.028\end{array}$ & $\begin{array}{r}-0.179 \\
0.028\end{array}$ & $\begin{array}{r}-0.184 \\
0.028\end{array}$ & $\begin{array}{r}-0.214 \\
0.069\end{array}$ \\
\hline $\ln \left(K_{0}\right)$ & - & $\begin{array}{r}-0.413 \\
0.059\end{array}$ & $\begin{array}{r}-0.406 \\
0.059\end{array}$ & $\begin{array}{r}-0.408 \\
0.057\end{array}$ & $\begin{array}{r}-0.333 \\
0.015\end{array}$ & $\begin{array}{r}-0.335 \\
0.015\end{array}$ & $\begin{array}{r}-0.331 \\
0.041\end{array}$ \\
\hline$M S_{0}$ & - & $\begin{array}{c}-0.491 \\
0.408\end{array}$ & $\begin{array}{r}-0 \cdot 264 \\
0 \cdot 365\end{array}$ & $\begin{array}{r}-0.031 \\
0.343\end{array}$ & $\begin{array}{r}-0.089 \\
0.342\end{array}$ & $\begin{array}{r}-0.305 \\
0.342\end{array}$ & $\begin{array}{r}-0.033 \\
0.720\end{array}$ \\
\hline $\begin{array}{l}\text { Sargan (df) } \\
p \text {-value }\end{array}$ & - & - & - & - & - & $\begin{array}{c}325(220) \\
0.000\end{array}$ & $\begin{array}{c}207(192) \\
0 \cdot 216\end{array}$ \\
\hline Observations & 3511 & 3511 & 3511 & 3511 & 3511 & 3511 & 3211 \\
\hline Years & $1972-1982$ & $1972-1982$ & 1972-1982 & $1972-1982$ & $1972-1982$ & $1972-1982$ & 1973-1982 \\
\hline$v_{1}$ & $10 \cdot 21$ & 11.03 & 10.98 & $11 \cdot 16$ & $11 \cdot 11$ & 11.00 & $9 \cdot 82$ \\
\hline $\begin{array}{l}v_{2} \\
R^{2}(P-S)\end{array}$ & $\begin{array}{c}9 \cdot 36 \\
0.842\end{array}$ & $\begin{array}{l}10 \cdot 19 \\
0 \cdot 862\end{array}$ & $\begin{array}{l}10 \cdot 13 \\
0.863\end{array}$ & $\begin{array}{l}10 \cdot 27 \\
0.863\end{array}$ & $\begin{array}{l}10 \cdot 19 \\
0 \cdot 389\end{array}$ & $9 \cdot 97$ & $8 \cdot 16$ \\
\hline
\end{tabular}

Notes. ${ }^{a}$ Coefficients and standard errors divided by 100 . A full set of time dummies, a dummy for the chemical sector, $\ln$ (inventories) are included as additional controls in all specifications. Initial stock of $\log$ (inventories) is included in columns (2)-(7). Standard errors are in italics and allow for arbitrary heteroskedasticity. All industry level variables are assumed exogenous. Instruments for firm level variables $\left(X_{t}\right)$ are: columns $X_{t-1}$ in (1)-(5); $X_{t-1}$ to $X_{t-7}$ in column (6) and $\Delta X_{t-1}$ to $\Delta X_{t-7}$ (except the interaction) in column (7). The Sargan test is distributed $\chi^{2}$ under the null of instrument validity. $R^{2}(P-S)$ are calculated as in Pesaran and Smith (1994).

significant, but market share is driven into insignificance (although the coefficient remains positive).

Following equation (2.5), and in order to investigate the factors shaping the value of an innovation, the innovation stock is interacted with market share in column (3). The interaction is highly significant and positive, implying that the innovations of high market share firms receive a greater value on the stock exchange. The high point estimate on the interaction term is due to the very low mean and highly skewed distribution of the variables. The marginal effect of market share in column (3) is 0.075 evaluated at median $G$ / 
$K(0)$ and 0.663 evaluated at mean $G / K(0.0037)$. The marginal effect of $G / K$ is 2.84 at median market share (0.009) and 7.77 at mean market share (0.040).

As an alternative specification, interactions between normalized innovation stock and other variables were included. These did not substantially effect the market share interaction and the extra interactions were generally insignificant. ${ }^{23}$ Industry controls are included in column (4) to capture industry wide competition, rival innovative activity and union power. Companies in industries which are highly concentrated or have little import penetration have higher market values. This is not surprising, nor is the fact that firms located in more heavily unionized industries appear to have lower market values. ${ }^{24}$ The hypothesis that the coefficient on physical capital is unity cannot be rejected in columns (2)-(4). Consequently the restriction is imposed and columns (5)-(7) present estimates of an "average $q$ " equation.

To check the robustness of the results many other experiments were implemented. First, we experimented with other functional forms of market share and the interaction of market share with the innovations stock. The positive effect of the interaction was robust to different functional forms and there was some evidence that the main effect is driven by firms in the top decile of market share. ${ }^{25}$ Second, using a slower depreciation rate $(15 \%)$ caused the coefficients on the innovation stock variables to fall, but the interaction is still significant at conventional levels. The linear knowledge term entered with a coefficient (standard error) of $0.492(0.385)$ and the interaction with market share took a value of $1 \cdot 152(0 \cdot 229) .^{26}$

Despite our attempts, it may be that permanent firm effects have not been adequately controlled for. This is suggested by the serial correlation tests in Table 4.2. Two alternative estimation strategies are implemented. First, lagged differences are used as instruments in the levels equation (column (7) of Table 4.2); second, a more conventional growth equation is implemented (Table 4.3). As a precursor to a first method column (6) uses a GMM approach efficiently exploiting more of the moment restrictions available from the assumed error structure. The instruments are the lagged levels of the firm level variables from $t-1$ up to a maximum of $t-7$. This marginally improves the precision of the estimated coefficients. The GMM approach gives overidentifying restrictions which allows a test of the assumed error structure. The Sargan statistic reported at the base of column (6) strongly rejects the absence of correlation of the residuals with the instruments, which suggests that unobservable heterogeneity has not been fully controlled for by conditioning on the initial stocks.

Column (7) implements the Arellano and Bover (1995) suggestion of using lagged differences as instruments. The Sargan statistic now fails to reject at conventional levels, suggesting that the problem was related to the fixed effects causing autocorrelation in the

23. The time dummy interactions with innovation stocks did suggest that companies with high innovation stocks enjoyed a significantly faster growth in their market values over this time period.

24. Instrumenting the industry variables with their own lagged values made little difference to the results. Including the initial values of the industry level variables did not substantially affect the signs of the firm level estimates.

25. For example, we created dummy variables MED (medium market share-firms with market shares lying between the median and 90th percentile) and HIGH (firms with market shares in the top decile). These were then interacted with the innovations stock variable and included (along with the linear terms) in column (4). The resulting equation was (standard errors in parentheses):

$$
\begin{aligned}
\ln (V / K)= & 2 \cdot 10(1 \cdot 03)(G / K)+0 \cdot 28(0 \cdot 07) \mathrm{MED}+ \\
& +0 \cdot 58(0 \cdot 10) \mathrm{HIGH}+3 \cdot 88(2 \cdot 37)[\mathrm{MED} *(G / K)] \\
& +31 \cdot 83(4 \cdot 26)[\mathrm{HIGH} *(G / K)]+\text { other controls. }
\end{aligned}
$$

26. The coefficients and standard errors have been divided by 100 as in the table. 
TABLE 4.3

Growth of market value

\begin{tabular}{|c|c|c|c|c|c|c|c|}
\hline & \multicolumn{5}{|c|}{$\frac{V_{t}-V_{t-1}}{V_{t-1}}$} & \multicolumn{2}{|c|}{$\frac{(V / K)_{t}-(V / K)_{t-1}}{(V / K)_{t-1}}$} \\
\hline & $\begin{array}{l}(1) \\
\text { all }\end{array}$ & $\begin{array}{c}(2) \\
\text { low } M S\end{array}$ & $\begin{array}{c}\text { (3) } \\
\text { high } M S\end{array}$ & $\begin{array}{c}(4) \\
\text { low } M S\end{array}$ & $\begin{array}{c}(5) \\
\text { high } M S\end{array}$ & $\begin{array}{c}(6) \\
\text { low } M S\end{array}$ & $\begin{array}{c}\text { (7) } \\
\text { high } M S\end{array}$ \\
\hline Surprise $I$ & $\begin{array}{l}0.023 \\
0.013\end{array}$ & $\begin{array}{l}0.011 \\
0.045\end{array}$ & $\begin{array}{l}0.026 \\
0.013\end{array}$ & $\begin{array}{l}0.008 \\
0.043\end{array}$ & $\begin{array}{l}0.023 \\
0.013\end{array}$ & $\begin{array}{l}0.006 \\
0.044\end{array}$ & $\begin{array}{l}0.026 \\
0.012\end{array}$ \\
\hline$\Delta K / K_{-1}$ & $\begin{array}{l}0 \cdot 246 \\
0 \cdot 066\end{array}$ & $\begin{array}{l}0.237 \\
0.081\end{array}$ & $\begin{array}{l}0.276 \\
0 \cdot 109\end{array}$ & $\begin{array}{l}0 \cdot 120 \\
0 \cdot 081\end{array}$ & $\begin{array}{l}0 \cdot 173 \\
0 \cdot 106\end{array}$ & - & - \\
\hline$\Delta M S / M S_{-1}$ & - & - & - & $\begin{array}{l}0.244 \\
0.058\end{array}$ & $\begin{array}{l}0 \cdot 270 \\
0 \cdot 062\end{array}$ & $\begin{array}{l}0 \cdot 112 \\
0 \cdot 060\end{array}$ & $\begin{array}{l}0 \cdot 176 \\
0 \cdot 064\end{array}$ \\
\hline$\Delta$ Conc $/$ Conc $_{-1}$ & - & - & - & $\begin{array}{r}-0.023 \\
0 \cdot 115\end{array}$ & $\begin{array}{r}-0.029 \\
0.072\end{array}$ & $\begin{array}{l}0.041 \\
0 \cdot 119\end{array}$ & $\begin{array}{r}-0.008 \\
0.076\end{array}$ \\
\hline$\Delta \mathrm{Imps} / \mathrm{Imps}_{-1}$ & - & - & - & $\begin{array}{r}-0.010 \\
0.084\end{array}$ & $\begin{array}{r}-0.026 \\
0.055\end{array}$ & $\begin{array}{l}0.023 \\
0.086\end{array}$ & $\begin{array}{r}-0.014 \\
0.056\end{array}$ \\
\hline$\Delta$ Union/Union $_{-1}$ & - & - & - & $\begin{array}{l}0 \cdot 015 \\
0 \cdot 206\end{array}$ & $\begin{array}{l}0.156 \\
0 \cdot 177\end{array}$ & $\begin{array}{l}0.033 \\
0 \cdot 208\end{array}$ & $\begin{array}{l}0 \cdot 201 \\
0 \cdot 176\end{array}$ \\
\hline$\Delta G$-user $/ G$-User ${ }_{-1}$ & - & - & - & $\begin{array}{r}-0.080 \\
0 \cdot 390\end{array}$ & $\begin{array}{r}-0.070 \\
0.365\end{array}$ & $\begin{array}{r}-0.192 \\
0.397\end{array}$ & $\begin{array}{r}-0.170 \\
0.370\end{array}$ \\
\hline$\Delta G$-prod $/ G$-Prod $_{-1}$ & - & - & - & $\begin{array}{l}0.678 \\
0 \cdot 165 \\
\end{array}$ & $\begin{array}{l}0.413 \\
0.113 \\
\end{array}$ & $\begin{array}{l}0.675 \\
0.168 \\
\end{array}$ & $\begin{array}{l}0.377 \\
0.186 \\
\end{array}$ \\
\hline $\begin{array}{l}\bar{R}^{2} \\
\text { Observations } \\
v_{1} \\
v_{2} \\
\text { Residual test } \\
p \text {-value } \\
\text { Years }\end{array}$ & $\begin{array}{c}0.440 \\
3286 \\
1 \cdot 788 \\
-1 \cdot 118 \\
0.850 \\
0 \cdot 395 \\
1973-1982\end{array}$ & $\begin{array}{c}0.416 \\
1694 \\
0.698 \\
-0.404 \\
0.089 \\
0.929 \\
1973-1982\end{array}$ & $\begin{array}{c}0.488 \\
1592 \\
1.680 \\
-0.221 \\
0.826 \\
0.409 \\
1973-1982\end{array}$ & $\begin{array}{c}0.431 \\
1694 \\
0.130 \\
-0.869 \\
-0.070 \\
0.944 \\
1973-1982\end{array}$ & $\begin{array}{c}0.497 \\
1592 \\
0.982 \\
-0.897 \\
0.454 \\
0.670 \\
1973-1982\end{array}$ & $\begin{array}{c}0.438 \\
1694 \\
0 \cdot 114 \\
-1 \cdot 607 \\
-0 \cdot 182 \\
0 \cdot 856 \\
1973-1982\end{array}$ & $\begin{array}{c}0.515 \\
1592 \\
0.850 \\
-0.835 \\
0.336 \\
0.737 \\
1973-1982\end{array}$ \\
\hline
\end{tabular}

Notes: "Surprise $I$ " is the residual from the innovation equation in linear form (Table 4.1, column 3). All other variables are measured in proportionate growth rates. Estimation is by OLS. A full set of time dummies and the change of inventories are included in all specifications. The residual test is the $t$-statistic and $p$-value of the coefficient of the lagged dependent variable regressed on the estimated residual. Standard errors are in italic and allow for arbitrary heteroskedasticity. Low $M S$ firms are those with market shares below $0.9 \%$, large market shares are those above $0.9 \%$ (approximately the sample median).

errors and rendering the instrumentation strategy of columns (1)-(6) invalid. The good news is that the coefficients on the innovation terms appear, if anything, to be biased downwards by the failure to control for correlated permanent effects, even though they are estimated with much less precision. The point estimate on the linear innovation stock terms in column (7) is approximately twice as large as that in column (6). The point estimate on the interaction term is practically identical.

An alternative and more conventional route is to consider a model for the growth in value. A problem with this, as discussed in the modelling section, is that only "news" should affect the change in the stock market value. Therefore, only the unpredicted part of innovation is used in the growth specification. This specification is likely to exaggerate timing and measurement error difficulties but clearly eliminates the influence of correlated permanent fixed effects.

Table 4.3 presents OLS estimates of equation (2.6). In columns (1)-(5) the dependent variable is the proportionate growth in the value of the firm. The first column simply includes the surprise innovation term and the proportionate growth of the physical capital stock. ${ }^{27}$ These were included due to the possible correlation of surprise innovation with

27. There may be some endogeneity remaining in the surprise term if there are events correlated with the observables and the surprise term. There are no obvious instruments, however. Lagged surprises should be uncorrelated with current surprises if stock markets use information efficiently. 
contemporaneous value-related events. The innovation term enters positively and implies that a surprise innovation is associated with an increase in the firm's value of $2.3 \%$. Since the average market value of firms in our sample is $£ 96.3$ million (1980 prices) this implies that a surprise innovation is typically associated with a rise in a firm's market value of around $£ 2 \cdot 21$ million. $^{28}$

In columns (2) and (3) the sample is split on the basis of whether lagged market share was "high" or "low". It is interesting that among the low market share firms a surprise innovation is associated with only about a $1 \%$ growth in market value, and is insignificant at conventional levels. For the high market share firms, however, there is a quantitatively larger $(2 \cdot 6 \%)$ and statistically significant impact. In columns (4) and (5) the model is saturated by including a full set of controls and the conclusion remains robust. Columns (6) and (7) repeat the saturated model using the growth of average $q$ as the dependent variable. Across all the specifications, high market share companies enjoy a proportionately larger pay-off from innovation. In absolute terms, the difference is even more substantial as market value is on average larger for high market share firms. ${ }^{29}$

The assumption that market value accurately measures the true position of the firm depends on the hypothesis that agents in the financial markets use information optimally. As a check on this assumption the residuals from each model in Table 4.3 were regressed against the lagged dependent variable (change in market value). Under the hypothesis of stock market efficiency, these lagged values should have no predictive power for the residuals. The residual test in Table 4.3 shows that this was indeed the case for all specifications. A further piece of evidence is the absence of serial correlation in the residuals. The hypothesis of weak stock market efficiency cannot be rejected. Including dividends in the definition of the growth of market value ${ }^{30}$ produced almost identical results.

A further criticism of our model is that innovations are simply added together. To avoid relying on the counts of innovation an innovation was redefined as unity if at least one innovation was recorded for an observation. Instead of the LFM a simple logit version of the specification in column (3) of Table 4.1 was used. The pattern of coefficients on the news terms were similar to those reported in Table 4.3, but were determined with far less precision. ${ }^{31}$ This suggests that the counts of greater than one, although comparatively rare, are supplying useful information in calculating the average value associated with an innovation.

\section{INDUSTRY HETEROGENEITY}

\subsection{Industry interactions}

In our main results we have pooled the data across the manufacturing sector. Although we have allowed for multiplicative firm specific effects in our innovation equation it may

28. The predicted profitability from a single SPRU innovation based on accounting profitability data was $£ 2.1$ million in the (undiscounted) long-run according to Geroski, Machin and Van Reenen (1993).

29. The mean market value for high market share firms is $£ 216$ million and for low market share firms is $£ 33$ million.

30. The growth of the market value of the firm was constructed using the following formula:

$$
v=\frac{V_{t}+D I V_{t}-V_{t-1}}{V_{t-1}}
$$

where $D I V_{t}$ is the real value of dividends paid out in year $t$. This is included to reflect the fact that the shareholders benefit both from the capital gain over the course of the year and any dividend pay-outs.

31. The coefficients on the surprise term in column (2) was -0.005 with a standard error of 0.050 . The equivalent numbers for the high market share firms in column (3) were 0.036 and 0.030. 
well be that $\beta$ parameters themselves vary systematically across industries. As a consequent it is reasonable to ask how stable are the coefficients across different industries? From an initial specification search including all interactions we found that three industries showed some evidence of deviating from the pooled model specification in column (3) of Table 4.1. These corresponded to the higher innovation industries: pharmaceuticals, non-pharmaceutical chemicals and electrical engineering. Labelling these industries $D R U G, C H E M$ and $E L E C$ respectively, the additional estimated interaction terms had the form (robust standard errors below coefficients)

$$
\underset{(1.700)}{2 \cdot 089 D R U} * M S_{i t-1}+\underset{(3.549)}{1 \cdot 176 C H E M} * M S_{i t-1}+\underset{(1.837)}{2 \cdot 238 E L E C * M S_{I t-1}} \text {. }
$$

However, these three interactions (and the more extended industry interactions) are not jointly significant, the Wald $\chi^{2}(3)$ test statistic having a value $2 \cdot 353$.

Apart from this simple analysis of interactions there are other aspects of innovation activity that can be usefully revealed from an industry level analysis and for this we chose to look specifically at the pharmaceutical industry, the leading innovation industry in our data.

\subsection{A case study: The pharmaceutical industry}

The basic dataset was augmented with more detailed information on firms operating in the pharmaceutical sector. This sector is of particular interest for several reasons. First, it is the leading high technology sector of the U.K. economy having both the highest R\&D to sales ratio of any major industry and accounting for about $20 \%$ all business enterprise R\&D in Britain. Secondly, patent protection is strong in this industry and companies generally recognize they are in races with other firms to develop innovative new products. Thus it has features consistent with the simple model outlined in Section 2. Finally, there is a wealth of data on the industry and it was possible to obtain information on the distribution of sales by each firm across different industries. Thus we were able to calculate the market share of each firm within the pharmaceutical sector. ${ }^{32}$ This enables a distinction to be made between the overall size of the firm (proxied by its total sales across all industries) and its market share (specific to the drugs industry). Notice that this identification strategy relies on the existence of firms operating across more than one industry.

Analyzing a single industry has costs as well as benefits. Since all the industry variables will have only time series variation their impact cannot be identified independently from time dummies. Additionally the sample size is far smaller than the overall sample (there are only 173 observations in the dataset which have a presence in the pharmaceutical industry and for which we have full within sample information on all the variables of interest).

The first regression is the model in column (3) of Table 4.1. Innovations are defined to be those solely relating to the pharmaceutical industry. This means, for example, that only a minority of the innovations of ICI (a large chemical company) are included in the definition of pharmaceutical innovations. The innovation equation results were of the following form (robust standard errors below coefficients)

$$
\ln E\left(I_{i t}\right)=\underset{(3.418)}{7.725 M S_{i t-1}} \underset{(0.905)}{0.259 S A L E S_{i t-1}}+\text { other controls; } \mathrm{NT}=173 .
$$

32. A valid criticism is that market shares are at too high a level of aggregation. Sutton (1998) uses market share data by therapeutic class (below 5 digit level). Unfortunately, such detailed data are not available to us over our time period. 
Other controls include a dummy for pre-sample innovation, capital stock, industry innovations stock and recession dummies. The elasticity ${ }^{33}$ of innovations with respect to market share, evaluated at mean market share, is $0 \cdot 61$. This compares to an elasticity ${ }^{34}$ of 0.50 for the pharmaceutical industry calculated using the estimates from column (2) of Table 4.1. Whereas the market share variable is significant at conventional levels the size variable (firm sales) attracts a negative coefficient, although it is completely insignificant. Although the two variables are correlated, the positive relationship between market share and innovation appears stronger than that between firm size and innovation, at least for this sample of firms.

The next experiment is to estimate the market value equation. Using the preferred average $q$ formulation and including interactions in both sales and market value led to the following result (robust standard errors below coefficients)

$$
\begin{aligned}
\ln (V / K)_{i t}= & \underset{(0.009)}{0.027}(G / K)_{i t}+\underset{(0.023)}{0.031}\{(G / K) * M S\}_{i t} \underset{(0.021)}{0.061}\{(G / K) * S A L E S\}_{i t} \\
& + \text { other controls; } \mathrm{NT}=173 .
\end{aligned}
$$

Other controls included linear $M S$ and SALES, and all other controls from column (5) of Table 4.2. It appears that there is a large and statistically significant correlation of innovation stocks with market value. The interaction between market share and innovations is positive, although imprecisely estimated. The interaction of innovations and company size (as proxied by sales) is, however, significantly negative. Finally, we estimated the change in market value equations split by large and small market share. In the sample of firms with higher market shares surprise innovations are associated with revisions to market value of about of 19\%. By comparison, low share firms have tiny (and negative) returns $(-0.7 \%)$. When the sample is split again into high and low firm size (using mean lagged sales), it is found that firms with smaller sales actually appear to get higher returns.

Although all these estimates suffer from lack of precision due to small sample size, they appear consistent with the tenor of our results on the overall sample. Firms with high market shares innovate more and get higher returns to their innovations when they do. The new information is that the effects identified are distinct from pure size effects (as measured by total firm sales).

\section{ALTERNATIVE MEASURES OF INNOVATIVE OUTPUT}

Innovation headcounts are often criticized for being too subjective as a measure of innovative output. A commonly used alternative is patent counts. However, patents have well known problems, not the least of which is that the great majority are believed to be of effectively zero economic value. ${ }^{35}$ Nevertheless, as a specification test it is useful to examine whether replacing innovations with an alternative measure of innovative output overturns any of our results. ${ }^{36}$ One disadvantage of the patents measure is that data is only available from 1969 onwards. The 1969-1973 averages are used to construct pre-sample histories and the estimation period begins in 1974. This is clearly less satisfactory than the much longer history available on the innovations measure.

33. This is from a static model so the elasticity is $\beta \bar{X}$. We found that dynamics were insignificant in the pharmaceutical sample.

34. The mean market share from the pooled sample was $\overline{M S}=0 \cdot 2$. Using the (preferred) LFM column (3) in Table 4.1, $\beta \bar{X}=2 \cdot 5(0 \cdot 2)$.

35. See, for example, Pakes (1986).

36. No attempt is made here to unravel the relationship between patents and innovations and whether they reflect distinct moments in the innovative process. 
Table 6.1 presents estimates of the patents equation in the first three columns and of the market value equation (in levels and growth rates) in the final three columns. Column (1) replaces innovations by patents as the dependent variable and shows a strong and positive effect of market share on patenting. Column (2) includes dynamics and the preentry patent stock variables (which are highly significant). The coefficient on market share falls to a quarter of its original value but remains strongly significant. There are some differences from the innovation equation. In particular, the capital stock variable completely reverses sign when we control for fixed effects. This is driven by the firms in the

TABLE 6.1

Patents

\begin{tabular}{|c|c|c|c|c|c|c|}
\hline \multirow[b]{2}{*}{ Dependent variable } & \multirow[b]{2}{*}{$\begin{array}{l}(1) \\
\text { Patents } \\
\text { LFM }\end{array}$} & \multirow[b]{2}{*}{$\begin{array}{l}\text { (2) } \\
\text { Patents } \\
\text { LFM }\end{array}$} & \multirow[b]{2}{*}{$\begin{array}{l}\text { (3) } \\
\text { Patents } \\
\text { LFM }\end{array}$} & \multirow[b]{2}{*}{$\begin{array}{c}(4) \\
V / K \\
\text { Levels }\end{array}$} & \multicolumn{2}{|c|}{$\frac{(V / K)_{t}-(V / K)_{t-1}}{(V / K)_{t-1}}$} \\
\hline & & & & & $\begin{array}{l}(5) \\
\text { Low } \\
M S\end{array}$ & $\begin{array}{l}(6) \\
\text { High } \\
M S\end{array}$ \\
\hline Patents $_{-1}$ & - & $\begin{array}{l}0.443 \\
0.084\end{array}$ & $\begin{array}{l}0.526 \\
0.098\end{array}$ & - & - & - \\
\hline$M S$ & $\begin{array}{l}5.662 \\
0.985\end{array}$ & $\begin{array}{l}1 \cdot 295 \\
0 \cdot 380\end{array}$ & $\begin{array}{l}1 \cdot 576 \\
0 \cdot 375\end{array}$ & $\begin{array}{l}0.854 \\
0.468\end{array}$ & $\begin{array}{l}0 \cdot 163 \\
0 \cdot 088\end{array}$ & $\begin{array}{l}0.241 \\
0.065\end{array}$ \\
\hline Conc & $\begin{array}{r}-1.001 \\
0.974\end{array}$ & $\begin{array}{l}0.468 \\
0 \cdot 369\end{array}$ & $\begin{array}{l}0 \cdot 507 \\
0 \cdot 396\end{array}$ & $\begin{array}{l}0.223 \\
0.084\end{array}$ & $\begin{array}{r}-0.012 \\
0.128\end{array}$ & $\begin{array}{l}0.083 \\
0.084\end{array}$ \\
\hline Imports & $\begin{array}{l}0.822 \\
0.752\end{array}$ & $\begin{array}{l}0.480 \\
0.379\end{array}$ & $\begin{array}{l}1 \cdot 141 \\
0 \cdot 374\end{array}$ & $\begin{array}{r}-0.311 \\
0.128\end{array}$ & $\begin{array}{l}0.038 \\
0.074\end{array}$ & $\begin{array}{r}-0.015 \\
0.056\end{array}$ \\
\hline$G P / K$ & - & - & - & $\begin{array}{l}0.444 \\
0.157\end{array}$ & - & - \\
\hline$M S *(G P / K)^{a}$ & - & - & - & $\begin{array}{l}0 \cdot 102 \\
0 \cdot 015\end{array}$ & - & - \\
\hline Surprise patents & - & - & - & - & $\begin{array}{l}0.002 \\
0.013\end{array}$ & $\begin{array}{l}0.001 \\
0.002\end{array}$ \\
\hline$K$ & $\begin{array}{l}5 \cdot 002 \\
1 \cdot 453\end{array}$ & $\begin{array}{r}-2 \cdot 147 \\
0 \cdot 700\end{array}$ & $\begin{array}{l}4 \cdot 287 \\
4 \cdot 719\end{array}$ & - & - & - \\
\hline $\operatorname{Big} K$ & - & - & $\begin{array}{r}-0.390 \\
0.254\end{array}$ & - & - & - \\
\hline Industry patents & $\begin{array}{l}0.605 \\
0 \cdot 159\end{array}$ & $\begin{array}{l}0.077 \\
0.110\end{array}$ & $\begin{array}{l}0.098 \\
0.099\end{array}$ & $\begin{array}{c}0.001 \\
0.0003\end{array}$ & - & - \\
\hline$P_{0}$ & - & $\begin{array}{l}0.869 \\
0.043\end{array}$ & $\begin{array}{l}0.810 \\
0.066\end{array}$ & $\begin{array}{l}0.000 \\
0.001\end{array}$ & - & - \\
\hline$P_{0}$ dum & - & $\begin{array}{l}3 \cdot 510 \\
0.505\end{array}$ & $\begin{array}{l}3.203 \\
0.556\end{array}$ & $\begin{array}{l}0.058 \\
0.029\end{array}$ & - & - \\
\hline Constant & $\begin{array}{r}-0.299 \\
0.428 \\
\end{array}$ & $\begin{array}{r}-0.958 \\
0.282 \\
\end{array}$ & $\begin{array}{r}-1.413 \\
0.381 \\
\end{array}$ & $\begin{array}{r}-3.000 \\
0.085 \\
\end{array}$ & $\begin{array}{r}-0.736 \\
0.029 \\
\end{array}$ & $\begin{array}{r}-0.647 \\
0.028 \\
\end{array}$ \\
\hline $\begin{array}{l}\text { Years } \\
\text { Observations } \\
v_{1} \\
v_{2}\end{array}$ & $\begin{array}{c}1974-1982 \\
2943 \\
3 \cdot 286 \\
2 \cdot 721\end{array}$ & $\begin{array}{c}1974-1982 \\
2934 \\
-0.855 \\
1.946\end{array}$ & $\begin{array}{c}1974-1982 \\
2943 \\
-1.212 \\
1.309\end{array}$ & $\begin{array}{c}1974-1982 \\
2943 \\
10.984 \\
9.991\end{array}$ & $\begin{array}{c}1974-1982 \\
1515 \\
-0.067 \\
-0.574\end{array}$ & $\begin{array}{c}1974-82 \\
1428 \\
-0.344 \\
-0.819\end{array}$ \\
\hline
\end{tabular}

Notes: ${ }^{a}$ Coefficient and standard error multiplied by 100 . The sample contains 340 firms which had at least nine continuous observations. Standard errors are in italics. Patents Equation (columns (1)-(3)): all variables are lagged one period; additional variables (not reported) included are: dummy variables for GEC, ICI and recessions; Value Equation in levels (column (4)): all firm variables are instrumented with their own value at $t-1$; initial stocks of all variables and time dummies are included as additional controls; Growth of average $\boldsymbol{q}$ in columns (5)-(6): all variables are proportional growth rates, time dummies included; $v_{1}$ and $v_{2}$ are the standard serial correlation statistics from Arellano and Bond (1991) which are distributed $N(0,1)$ under the null of no serial correlation; robust standard errors under coefficients. 
largest decile of the capital stock distribution as column (3) illustrates ${ }^{37}$. This evidence of a non-monotonic relationship for capital did not appear to be a feature of the market share variable.

Column (4) contains the "average $q$ " equations in levels. The point estimates on the stock of patents is smaller than was the case for the innovation stock, although it is still highly significant. Even more encouraging is the fact that the interaction of patents with market share is significant and positive lending support to the view that high market share firms receive greater returns from their patent stocks. The one disappointment is that in the growth of value equations the surprise term is insignificant for both the high and low market share firms. Further investigation revealed that the patents surprise model is unrobust to the inclusion of a single very high patenting firm (ICI). Dropping this firm and re-estimating the growth in value equation restored the pattern observed in Table 4.3 where we considered surprise innovation. The coefficient (standard error) on surprise patents for high market share firms was $0.004(0.002)$ compared to $0.002(0.013)$ for low market share firms.

\section{CONCLUSION}

This paper has investigated the statistical robustness of the effect of market structure on innovation and its economic interpretation. Our approach has combined two strands in the literature on innovation by estimating both an innovation equation and a value equation on a novel firm panel level data source. Even though predetermined variables were used to model innovative activity and stock market value, it was clear that persistence in unobservables was likely to be important and would invalidate the use of such weakly exogenous variables. Rather than rely on the dubious assumption of strict exogeneity, the long series of "pre-sample" information on innovations and market value were used to control for unobserved heterogeneity. This estimator was shown to perform well in Monte Carlo simulation. When implementing a dynamic feedback model for company innovations, including the controls for firm specific effects, it was found that "less competitive" industries (those with lower import penetration and higher concentration levels) had fewer aggregate innovations. Nevertheless, within industries it was the high market share firms who tended to commercialize more innovations although increased product market competition in the industry tended to stimulate innovative activity. A direct effect of innovation was also found in the stock market value model (in levels or differences). More interestingly, the higher market share firms tended to benefit most from innovations. This was confirmed when estimating all equations within a particular industry (pharmaceuticals) and when patents were used as an entirely independent measure of technological capability.

We have argued that the results presented in this paper are in line with models where high market share firms have greater incentives to pre-emptively innovate. There are alternative interpretations of our results, however, and we mention two here. One argument is that leading firms have a systematic tendency to produce innovations that are intrinsically of higher quality than smaller firms. On one level this is entirely consistent with our model - the more intensive search of leading firms should enable them both to produce more and higher quality innovations. Nevertheless, the empirical literature on management behaviour suggests, if anything, that smaller firms are more likely to produce radical innovations. ${ }^{38}$ In the population of SPRU data covered by our firms there is no

37. Big $K$ is a dummy equal to unity if the observation's capital stock was in the top decile of the capital stock distribution. The linear $K$ is truncated at this point.

38. See Henderson (1993) for a summary. It should be emphasized, however, that in the diffusion process the larger firms may be better at putting these radical innovations into generlized use. 
significant correlation between the proportion of innovations classified as "radical" or "significant" (as opposed to incremental) by the SPRU experts and the size of the firm.

A separate rationalization of the results is that high market firms have marketing advantages over other firms. These marketing skills are very beneficial in promoting the sales of an innovation. Since it is more likely that marketing is a feature of firm size rather than share, as we are inclined against this interpretation. Nevertheless, without direct data on marketing expenditures, investigating this alternative will have to be left for future work.

It is often asserted that the superior performance of large firms in innovating is because they have higher cash flows from which to finance investment in R\&D. Our findings suggest that this is not the whole story-dominant firms innovate because they have a relatively greater incentive to do so. Firms with high market shares who innovate get a higher valuation on the stock market than those who do not.

\section{APPENDIX}

\section{Data}

The dataset used in this paper combines company accounts (Datastream International on-line service), share price information from the London Business School's Share Price Database and a count of innovations from the Science Policy Research Unit (SPRU). The sample includes manufacturing firms listed on the London International Stock Exchange for which at least nine continuous years of data were observed. Firms experiencing more than a $200 \%$ growth rate in any of the key variables (market value, capital, sales) were dropped from the sample. This left an unbalanced panel of 340 firms. Descriptive statistics on the variables are shown in Table A.1, numbers in italics are standard deviations.

$I_{i t}$ is the count of innovations commercialized by British firms. This data was collected by SPRU in three waves over a period of fifteen years and the full dataset includes over 4500 innovations. The SPRU researchers contacted a group of over 400 experts in science and industry who had detailed knowledge about the technological development in their own sectors of British industry. An innovation was defined as "the successful commercial introduction of new or improved products, processes or materials" introduced in Britain between 19451983. The experts identified the technical characteristics of these innovations, which firms first commercialized them, the date of commercialization, which industry the innovation was first produced in and where the innovation first had its most extensive usage. These responses were collated and the firms then contacted for more precise information concerning the date of commercialization and basic firm and innovation characteristics. The SPRU data is the major source of innovations research by economists in the U.K. and a comprehensive bibliography of secondary research is compiled in Geroski (1995). Robson, Townsend and Pavitt (1988) provide details about the characteristics of the population of innovations.

With regards to their time series profile between 1945-1982, innovations exhibit procyclical behaviour and cluster around the peak of business cycles. Data for the year 1983 was dropped because there is a large fall in the number of innovations induced by the fact that the survey was concluded towards the end of the year (as also occurred in the last year of the previous two waves of the survey). The pattern of innovations across industries appears broadly stable over time, with the bulk concentrated in five industries: pharmaceuticals, nonpharmaceutical chemicals, electrical engineering, mechanical engineering and vehicles. Almost all of the innovations in the dataset originate in the manufacturing sector, although non-manufacturing firms were large users. The innovations are a mixture of product and process innovations and there is no simple way in the data to distinguish between the two types. Examples of innovations include optical fibres for telecommunications, solar glass windows, Interforen, copper/aluminium superplastic furniture and the Magnascan 560 colour scanner. The dataset is lodged at the ESRC Data Archive at the University of Essex.

The SPRU innovations data were matched to company accounts by name using information on parents and subsidiaries from Dun and Bradstreet's Who Owns Whom from various years. The innovation stocks of a firm include the stocks of firms that it has taken over. The sample used in this paper holds about $25 \%$ of the population of innovations. Most of the losses are due to the fact that the sample is restricted to relatively large firms (due to the necessity to have stock market data), whereas many SPRU innovations were commercialized by small firms (Pavitt, Robson and Townsend (1987)). However, the subsample of the innovations population used in this paper has similar characteristics to the aggregate data. An important difference, however, is that 
TABLE A.1

Descriptive statistics

\begin{tabular}{|c|c|c|c|c|}
\hline Variable & $\begin{array}{c}\text { Firms } \\
\text { Observations }\end{array}$ & $\begin{array}{c}\text { All firms } \\
340 \\
3551\end{array}$ & $\begin{array}{c}\text { Innovating firms } \\
115 \\
1228\end{array}$ & $\begin{array}{c}\text { Non-innovating } \\
\text { firms } \\
225 \\
2323\end{array}$ \\
\hline $\begin{array}{l}\text { Firm level variables } \\
\text { Innovations }\end{array}$ & $I$ & $\begin{array}{l}0 \cdot 109 \\
0.663\end{array}$ & $\begin{array}{l}0.316 \\
1.099\end{array}$ & - \\
\hline Patents & $P$ & $\begin{array}{r}2 \cdot 151 \\
35 \cdot 224\end{array}$ & $\begin{array}{r}5.967 \\
22 \cdot 852\end{array}$ & $\begin{array}{r}0 \cdot 140 \\
31 \cdot 373\end{array}$ \\
\hline Innovation stock & $G$ & $\begin{array}{l}0.369 \\
1.790\end{array}$ & $\begin{array}{l}1 \cdot 068 \\
2.918\end{array}$ & - \\
\hline Market share & $M S$ & $\begin{array}{l}0.040 \\
0 \cdot 089\end{array}$ & $\begin{array}{l}0 \cdot 078 \\
0 \cdot 123\end{array}$ & $\begin{array}{l}0.020 \\
0.054\end{array}$ \\
\hline Market value & Value & $\begin{array}{l}0.075 \\
0 \cdot 211\end{array}$ & $\begin{array}{l}0 \cdot 169 \\
0 \cdot 387\end{array}$ & $\begin{array}{l}0.026 \\
0.052\end{array}$ \\
\hline Tangible capital & Capital & $\begin{array}{l}0.014 \\
0 \cdot 045\end{array}$ & $\begin{array}{l}0.031 \\
0.071\end{array}$ & $\begin{array}{l}0.005 \\
0.012\end{array}$ \\
\hline Cash flow & Cash & $\begin{array}{l}0 \cdot 152 \\
0 \cdot 641\end{array}$ & $\begin{array}{l}0 \cdot 130 \\
0 \cdot 153\end{array}$ & $\begin{array}{l}0 \cdot 164 \\
0.784\end{array}$ \\
\hline $\begin{array}{l}\text { Industry level variables } \\
\text { Concentration }\end{array}$ & Conc & $\begin{array}{l}0 \cdot 417 \\
0 \cdot 171\end{array}$ & $\begin{array}{l}0 \cdot 417 \\
0 \cdot 158\end{array}$ & $\begin{array}{l}0.417 \\
0 \cdot 177\end{array}$ \\
\hline Import penetration & Imports & $\begin{array}{l}0 \cdot 242 \\
0 \cdot 141\end{array}$ & $\begin{array}{l}0 \cdot 254 \\
0 \cdot 127\end{array}$ & $\begin{array}{l}0.236 \\
0 \cdot 148\end{array}$ \\
\hline Union density & Union & $\begin{array}{l}0.656 \\
0 \cdot 116\end{array}$ & $\begin{array}{l}0 \cdot 676 \\
0 \cdot 103\end{array}$ & $\begin{array}{l}0.646 \\
0 \cdot 121\end{array}$ \\
\hline Producer knowledge stock & $G$-Prod & $\begin{array}{l}0.338 \\
0.491\end{array}$ & $\begin{array}{l}0.414 \\
0.526\end{array}$ & $\begin{array}{l}0.298 \\
0.467\end{array}$ \\
\hline User innovation stock & $G$-User & $\begin{array}{l}0 \cdot 130 \\
0 \cdot 141\end{array}$ & $\begin{array}{l}0 \cdot 155 \\
0 \cdot 144\end{array}$ & $\begin{array}{l}0 \cdot 177 \\
0 \cdot 137\end{array}$ \\
\hline
\end{tabular}

Notes: $\quad$ Market Value, Capital, Stocks and Cash Flow are all measured in $1980 £$ billions. In the table innovating firms include all firms who had at least one innovation within or pre-sample. Standard deviations in italics below means

the sample includes both innovators and non-innovators. Around one-third of the firms in the sample innovated at some time. The largest number of innovations was by GEC and its subsidiaries which commercialized a total of 90 innovations between 1972 and 1982. However, most firms that innovated only had one or two innovations. The majority of observations (one firm in one year) contained zero innovations $(94 \%)$.

A note on sample selectivity is in order. The sample is based on the population of Stock Exchange companies so there is therefore a bias towards larger more multinational firms. There may be some survival bias arising from the fact that we condition our sample on firms that have been continuously on the stock market for at least nine years. We have not conditioned on having a fully balanced sample so survival bias should be mitigated. Relaxing the criteria to have fewer continuous time series observations (e.g. seven) did not make a substantial difference to the results. Also, controlling for fixed effects should also mitigate selectivity problems.

Innovation stock, $G_{i t}$, is as given by equation (2.3) with a depreciation rate of $30 \%$ (see the text for alternative depreciation rates). As described in Section 3, $G_{0}$ is the firm's innovation stock when it enters the sample. This is supplemented with a dummy variable equal to one if the firm ever innovated in the pre-sample period that captures the fact that firms who ever innovate may be qualitatively different from those who never innovate $\left(G_{0}\right.$ dum $)$. The other variables used are:

G-Prod. The numbers of innovations produced in a firm's principal two digit operating industry was calculated using the entire SPRU database and transformed into a stock in the same way as $G_{i t}$.

$G$-User. The numbers of innovations used in a firm's principal two digit operating industry was calculated using the entire SPRU database and transformed into a stock in the same way as $G_{i t}$. 
MS. Market Share is the ratio of the firm's sales (Datastream Item 219) to sales in its principal three digit industry (Census of Production Table P1002a).

There is likely to be mismeasurement of this variable because of the presence of multi-industry firms, but controls for the fixed effect should deal with this if the mismeasurement is stable over time.

$K$. Capital is calculated to be the replacement cost of capital and is constructed from the investment flow information (Datastream Item 435) using the perpetual inventory method. For full details of this method see Blundell et al. (1992).

$V$. Market value is measured by the product of the company's outstanding shares and the price of these shares on December 31st. This is then added to the value of outstanding debt.

$P$. Patents are the number of patents granted to the firm by the U.S. Patent Office in a particular year. U.S. Patents were chosen to screen out the huge number of very low value patents granted. They were matched into the firm accounts by the same method as the innovations data. Patents stocks were calculated in the same way as innovations stocks with the exception that the base year is 1969 instead of 1945.

Industry Patents. Number of patents in a firms's two digit industry aggregated from the population of Datastream firms (net of firm's own patents).

Conc. Concentration is the proportion of sales that is represented by the five largest domestic firms in the firm's three digit industry (Census of Production Table P1002a).

Imports. Import penetration is the value of imports over home demand in the firm's industry (Business Monitor Table M012).

Union. Union density is the proportion of workers who are members of a trade union in the firm's two digit industry (Price and Bain (1983)).

Acknowledgements. This paper has benefitted from comments by Stephen Bond, Zvi Griliches, Paul Geroski, Bronwyn Hall, Tor Klette, Jacques Mairesse, Costas Meghir and Stephen Nickell. Special thanks are due to Manuel Arellano and Frank Windmeijer and three anonymous referees. Participants in seminars at Berkeley, Birkbeck, Bristol, Florence, London, the NBER, Paris, Tokyo and York University have also given many useful remarks. Responsibility for all errors remains our own.

\section{REFERENCES}

ARELLANO, M. and BOND, S. (1991), "Some Tests of Specification for Panel Data: Monte Carlo Evidence and an Application to Employment Equations", Review of Economic Studies, 58, 277-298.

ARELLANO, M. and BOVER, O. (1995), "Another Look at the Instrumental Variable Estimation of Error Components Models", Journal of Econometrics, 68, 29-52.

BEATH, J., KATSOULACOS, Y. and ULPH, D. (1991), "Strategic Innovation", Economic Journal, 101, 7483.

BHATTACHARYA, J. and RITTER, J. (1985), "Innovation and Communication: Signalling with Partial Disclosure", Review of Economic Studies, 50, 331-346.

BLUNDELL, R. and BOND, S. (1998), "Initial Conditions and Moment Restrictions in Dynamic Panel Data Models", Journal of Econometrics 87, 115-149.

BLUNDELL, R., BOND, S., DEVEREAUX, M. and SCHIANTARELLI, F. (1992), "Investment and Tobin's Q", Journal of Econometrics, 51, 233-257.

BLUNDELL, R., GRIFFITH, R. and VAN REENEN, J. (1995a), "Dynamic Count Data Models of Technological Innovation", Economic Journal, 105, 333-344.

BLUNDELL, R., GRIFFITH, R. and VAN REENEN, J. (1995b), "Market Share, Market Value and Innovation in a Panel of British Manufacturing Firms" (University College London: Discussion Paper in Economics No. 95/7).

BLUNDELL, R., GRIFFITH, R. and WINDMEIJER, F. (1995), “Individual Effects and Dynamic Feedback in Count Data Models" (IFS Working paper 99/9, http://ifs.org.uk/research/working papers/).

BUDD, C., HARRIS, C. and VICKERS, J. (1993), "A Model of the Evolution of Duopoly: Does the Asymmetry between Firms Tend to Increase or Decrease?", Review of Economic Studies, 60, 543-573.

CHAMBERLAIN, G. (1982), "Multivariate Regression Models for Panel Data", Journal of Econometrics, 18, $5-46$.

CHAMBERLAIN, G. (1992), "Comment: Sequential Moment Restrictions in Panel Data”, Journal of Business and Economic Statistics, 10, 20-26.

COHEN, W. and LEVIN, R. (1989), "Empirical Studies of Innovation and Market Structure", in R. Schmalensee and R. Willig (eds.), The Handbook of Industrial Organization, Volume I (Amsterdam: NorthHolland).

FISHER, F. and TEMIN, P. (1973), "Returns to Scale in Research and Development: What Does the Schumpeterian Hypothesis Imply?", Journal of Political Economy, 81, 56-70. 
GEROSKI, P. (1995) Market Structure, Corporate Performance and Innovative Activity (Oxford: Oxford University Press).

GEROSKI, P., MACHIN, S. and VAN REENEN, J. (1993), "The Profitability of Innovating Firms", Rand Journal of Economics, 24, 198-211.

GILBERT, R. and NEWBERY, D. (1982), "Preemptive Patenting and the Persistence of Monopoly", American Economic Review, 72, 514-526.

GRILICHES, Z. (1981), "Market Value, R\&D and Patents”, Economic Letters, 7, 183-187.

GRILICHES, Z. (1990), "Patent Statistics as Economic Indicators: A Survey", Journal of Economic Literature, 28, 1661-1707.

GRILICHES, Z., HALL, B. and PAKES, A. (1991), "R\&D, Patents and Market Value Revisited: Is There a Second (Technological Opportunity) Factor", Economic of Innovation and New Technology, 1, 183-202.

HALL, R. (1988), "The Relation Between Price and Marginal Cost in U.S. Industry", Journal of Political Economy, 96, 921-947.

HAUSMAN, J., HALL, B. and GRILICHES, Z. (1984), "Econometric Models for Count Data and an Application to the Patents-R\&D Relationship", Econometrica, 52, 909-938.

HARRIS, C. and VICKERS, J. (1987), "Racing with Uncertainty", Review of Economic Studies, 54, 1-21.

HENDERSON, R. (1993), "Underinvestment and Incompetence as Responses to Radical Innovation: Evidence from the Photolithographic Alignment Equipment Industry", Rand Journal of Economics, 24, $248-271$.

JAFFE, A. (1986), "Technological Opportunity and Spillovers of R\&D”, American Economic Review, 76, 9841001.

McKENZIE, E. (1988), "Some ARMA Models for Dependent Sequences of Poisson Counts", Advances in Applied Probability, 20, 822-835.

PAKES, A. (1985), "On Patents, R + D and the Stock Market Rate of Return", Journal of Political Economy, 93, 390-409.

PAKES, A. (1986), "Patents Options: Some Estimates of the Value of Holding European Patent Stocks", Econometrica, 54, 755-784.

PAVITT, K., ROBSON, M. and TOWNSEND, J. (1987), "The Size Distribution of Innovating Firms in the U.K.: 1945-83", Journal of Industrial Economics, 35, 297-316.

PESARAN, H. and SMITH, R. (1994), "A Generalized $R^{2}$ Criterio for Regression Models Estimated by the Instrumental Variable", Econometrica, 3, 705-710.

PRICE, R. and BAIN, G. (1983), "Union Growth in Britain: Retrospect and Prospect", British Journal of Industrial Relations, 21, 46-88.

REINGANUM, J. (1983), "Uncertain Innovation and the Persistence of Monopoly", American Economic Review, 73, 61-66.

REINGANUM, J. (1989), “The Timing of Innovation”, in R. Schmalensee and R. Willig (eds.), The Handbook of Industrial Organization, Volume I. (Amsterdam: North-Holland).

ROBSON, M., TOWNSEND, J. and PAVITT, K. (1988), "Sectoral Patterns of Production and Use of Innovations in the U.K.: 1945-83", Research Policy, 17, 1-14.

SCHERER, F. (1967), "Market Structure and the Employment of Scientists and Engineers", American Economic Review, 57, 524-531.

SCHUMPETER, J. (1939) Business Cycles (London: Allen and Unwin).

SUTTON, J. (1998), Technology and Market Structure (Cambridge: MIT Press).

WOOLDRIDGE, J. M. (1997), "Multiplicative Panel Data Models Without the Strict Exogeneity Assumption", Econometric Theory, 13, 667-678. 
http://www.jstor.org

\title{
LINKED CITATIONS
}

- Page 1 of 7 -

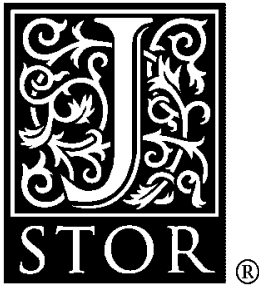

You have printed the following article:

Market Share, Market Value and Innovation in a Panel of British Manufacturing Firms

Richard Blundell; Rachel Griffith; John Van Reenen

The Review of Economic Studies, Vol. 66, No. 3. (Jul., 1999), pp. 529-554.

Stable URL:

http://links.jstor.org/sici?sici=0034-6527\%28199907\%2966\%3A3\%3C529\%3AMSMVAI\%3E2.0.CO\%3B2-5

This article references the following linked citations. If you are trying to access articles from an off-campus location, you may be required to first logon via your library web site to access JSTOR. Please visit your library's website or contact a librarian to learn about options for remote access to JSTOR.

\section{[Footnotes]}

\author{
${ }^{1}$ A Model of the Evolution of Duopoly: Does the Asymmetry between Firms Tend to Increase \\ or Decrease? \\ Christopher Budd; Christopher Harris; John Vickers \\ The Review of Economic Studies, Vol. 60, No. 3. (Jul., 1993), pp. 543-573. \\ Stable URL: \\ http://links.jstor.org/sici?sici=0034-6527\%28199307\%2960\%3A3\%3C543\%3AAMOTEO\%3E2.0.CO\%3B2-4

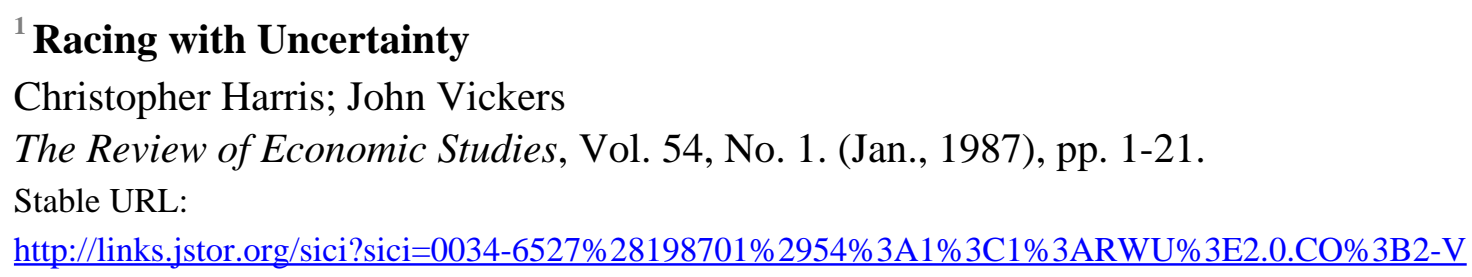

\footnotetext{
${ }^{2}$ Returns to Scale in Research and Development: What Does the Schumpeterian Hypothesis Imply?

Franklin M. Fisher; Peter Temin

The Journal of Political Economy, Vol. 81, No. 1. (Jan. - Feb., 1973), pp. 56-70.

Stable URL:

http://links.jstor.org/sici?sici=0022-3808\%28197301\%2F02\%2981\%3A1\%3C56\%3ARTSIRA\%3E2.0.CO\%3B2-S
}

NOTE: The reference numbering from the original has been maintained in this citation list. 
http://www.jstor.org

\title{
LINKED CITATIONS
}

- Page 2 of 7 -

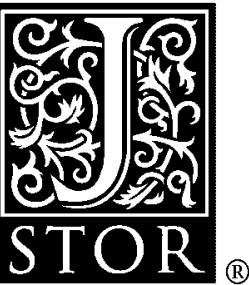

\footnotetext{
${ }^{3}$ Underinvestment and Incompetence as Responses to Radical Innovation: Evidence from the Photolithographic Alignment Equipment Industry

Rebecca Henderson

The RAND Journal of Economics, Vol. 24, No. 2. (Summer, 1993), pp. 248-270.

Stable URL:

http://links.jstor.org/sici?sici=0741-6261\%28199322\%2924\%3A2\%3C248\%3AUAIART\%3E2.0.CO\%3B2-M

\author{
${ }^{4}$ The Relation between Price and Marginal Cost in U.S. Industry \\ Robert E. Hall \\ The Journal of Political Economy, Vol. 96, No. 5. (Oct., 1988), pp. 921-947. \\ Stable URL: \\ http://links.jstor.org/sici?sici=0022-3808\%28198810\%2996\%3A5\%3C921\%3ATRBPAM\%3E2.0.CO\%3B2-G
}

\author{
${ }^{6}$ On Patents, R \& D, and the Stock Market Rate of Return \\ Ariel Pakes \\ The Journal of Political Economy, Vol. 93, No. 2. (Apr., 1985), pp. 390-409. \\ Stable URL: \\ http://links.jstor.org/sici?sici=0022-3808\%28198504\%2993\%3A2\%3C390\%3AOPR\%26DA\%3E2.0.CO\%3B2-1
}

\section{${ }^{7}$ Technological Opportunity and Spillovers of R \& D: Evidence from Firms' Patents, Profits, and Market Value}

Adam B. Jaffe

The American Economic Review, Vol. 76, No. 5. (Dec., 1986), pp. 984-1001.

Stable URL:

http://links.jstor.org/sici?sici=0002-8282\%28198612\%2976\%3A5\%3C984\%3ATOASOR\%3E2.0.CO\%3B2-M

\footnotetext{
${ }^{10}$ Some Tests of Specification for Panel Data: Monte Carlo Evidence and an Application to Employment Equations

Manuel Arellano; Stephen Bond

The Review of Economic Studies, Vol. 58, No. 2. (Apr., 1991), pp. 277-297.

Stable URL:

http://links.jstor.org/sici?sici=0034-6527\%28199104\%2958\%3A2\%3C277\%3ASTOSFP\%3E2.0.CO\%3B2-2
}

\footnotetext{
${ }^{11}$ Some ARMA Models for Dependent Sequences of Poisson Counts

Ed McKenzie

Advances in Applied Probability, Vol. 20, No. 4. (Dec., 1988), pp. 822-835.

Stable URL:

http://links.jstor.org/sici?sici=0001-8678\%28198812\%2920\%3A4\%3C822\%3ASAMFDS\%3E2.0.CO\%3B2-M
}

NOTE: The reference numbering from the original has been maintained in this citation list. 
http://www.jstor.org

\section{LINKED CITATIONS}

- Page 3 of 7 -

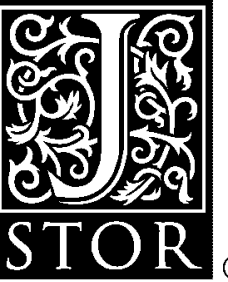

\section{${ }^{17}$ Dynamic Count Data Models of Technological Innovation}

Richard Blundell; Rachel Griffith; John Van Reenen

The Economic Journal, Vol. 105, No. 429. (Mar., 1995), pp. 333-344.

Stable URL:

http://links.jstor.org/sici?sici=0013-0133\%28199503\%29105\%3A429\%3C333\%3ADCDMOT\%3E2.0.CO\%3B2-H

\section{${ }^{28}$ The Profitability of Innovating Firms}

Paul Geroski; Steve Machin; John Van Reenen

The RAND Journal of Economics, Vol. 24, No. 2. (Summer, 1993), pp. 198-211.

Stable URL:

http://links.jstor.org/sici?sici=0741-6261\%28199322\%2924\%3A2\%3C198\%3ATPOIF\%3E2.0.CO\%3B2-1

${ }^{35}$ Patents as Options: Some Estimates of the Value of Holding European Patent Stocks Ariel Pakes

Econometrica, Vol. 54, No. 4. (Jul., 1986), pp. 755-784.

Stable URL:

http://links.jstor.org/sici?sici=0012-9682\%28198607\%2954\%3A4\%3C755\%3APAOSEO\%3E2.0.CO\%3B2-X

${ }^{38}$ Underinvestment and Incompetence as Responses to Radical Innovation: Evidence from the Photolithographic Alignment Equipment Industry

Rebecca Henderson

The RAND Journal of Economics, Vol. 24, No. 2. (Summer, 1993), pp. 248-270.

Stable URL:

http://links.jstor.org/sici?sici=0741-6261\%28199322\%2924\%3A2\%3C248\%3AUAIART\%3E2.0.CO\%3B2-M

\section{References}

Some Tests of Specification for Panel Data: Monte Carlo Evidence and an Application to Employment Equations

Manuel Arellano; Stephen Bond

The Review of Economic Studies, Vol. 58, No. 2. (Apr., 1991), pp. 277-297.

Stable URL:

http://links.jstor.org/sici?sici=0034-6527\%28199104\%2958\%3A2\%3C277\%3ASTOSFP\%3E2.0.CO\%3B2-2

NOTE: The reference numbering from the original has been maintained in this citation list. 
http://www.jstor.org

\title{
LINKED CITATIONS
}

- Page 4 of 7 -

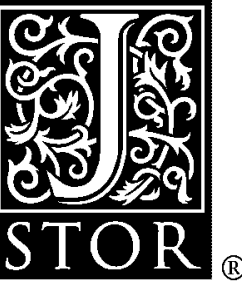

\section{Review: [Untitled]}

Reviewed Work(s):

The Theory of Technological Change and Economic Growth by Stanislaw Gomulka John Beath

The Economic Journal, Vol. 101, No. 408. (Sep., 1991), pp. 1309-1311.

Stable URL:

http://links.jstor.org/sici?sici=0013-0133\%28199109\%29101\%3A408\%3C1309\%3ATTOTCA\%3E2.0.CO\%3B2-G

\section{Innovation and Communication: Signalling with Partial Disclosure}

Sudipto Bhattacharya; Jay R. Ritter

The Review of Economic Studies, Vol. 50, No. 2. (Apr., 1983), pp. 331-346.

Stable URL:

http://links.jstor.org/sici?sici=0034-6527\%28198304\%2950\%3A2\%3C331\%3AIACSWP\%3E2.0.CO\%3B2-A

\section{Dynamic Count Data Models of Technological Innovation}

Richard Blundell; Rachel Griffith; John Van Reenen

The Economic Journal, Vol. 105, No. 429. (Mar., 1995), pp. 333-344.

Stable URL:

http://links.jstor.org/sici?sici=0013-0133\%28199503\%29105\%3A429\%3C333\%3ADCDMOT\%3E2.0.CO\%3B2-H

\author{
A Model of the Evolution of Duopoly: Does the Asymmetry between Firms Tend to Increase or \\ Decrease? \\ Christopher Budd; Christopher Harris; John Vickers \\ The Review of Economic Studies, Vol. 60, No. 3. (Jul., 1993), pp. 543-573. \\ Stable URL: \\ http://links.jstor.org/sici?sici=0034-6527\%28199307\%2960\%3A3\%3C543\%3AAMOTEO\%3E2.0.CO\%3B2-4
}

\section{Comment: Sequential Moment Restrictions in Panel Data}

Gary Chamberlain

Journal of Business \& Economic Statistics, Vol. 10, No. 1. (Jan., 1992), pp. 20-26.

Stable URL:

http://links.jstor.org/sici?sici=0735-0015\%28199201\%2910\%3A1\%3C20\%3ACSMRIP\%3E2.0.CO\%3B2-G

NOTE: The reference numbering from the original has been maintained in this citation list. 
http://www.jstor.org

\section{LINKED CITATIONS}

- Page 5 of 7 -

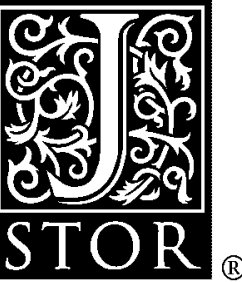

Returns to Scale in Research and Development: What Does the Schumpeterian Hypothesis Imply?

Franklin M. Fisher; Peter Temin

The Journal of Political Economy, Vol. 81, No. 1. (Jan. - Feb., 1973), pp. 56-70.

Stable URL:

http://links.jstor.org/sici?sici=0022-3808\%28197301\%2F02\%2981\%3A1\%3C56\%3ARTSIRA\%3E2.0.CO\%3B2-S

\section{The Profitability of Innovating Firms}

Paul Geroski; Steve Machin; John Van Reenen

The RAND Journal of Economics, Vol. 24, No. 2. (Summer, 1993), pp. 198-211.

Stable URL:

http://links.jstor.org/sici?sici=0741-6261\%28199322\%2924\%3A2\%3C198\%3ATPOIF\%3E2.0.CO\%3B2-1

\section{Preemptive Patenting and the Persistence of Monopoly}

Richard J. Gilbert; David M. G. Newbery

The American Economic Review, Vol. 72, No. 3. (Jun., 1982), pp. 514-526.

Stable URL:

http://links.jstor.org/sici?sici=0002-8282\%28198206\%2972\%3A3\%3C514\%3APPATPO\%3E2.0.CO\%3B2-N

\section{Patent Statistics as Economic Indicators: A Survey}

Zvi Griliches

Journal of Economic Literature, Vol. 28, No. 4. (Dec., 1990), pp. 1661-1707.

Stable URL:

http://links.jstor.org/sici?sici=0022-0515\%28199012\%2928\%3A4\%3C1661\%3APSAEIA\%3E2.0.CO\%3B2-2

\section{The Relation between Price and Marginal Cost in U.S. Industry}

Robert E. Hall

The Journal of Political Economy, Vol. 96, No. 5. (Oct., 1988), pp. 921-947.

Stable URL:

http://links.jstor.org/sici?sici=0022-3808\%28198810\%2996\%3A5\%3C921\%3ATRBPAM\%3E2.0.CO\%3B2-G

Econometric Models for Count Data with an Application to the Patents-R \& D Relationship Jerry Hausman; Bronwyn H. Hall; Zvi Griliches

Econometrica, Vol. 52, No. 4. (Jul., 1984), pp. 909-938.

Stable URL:

http://links.jstor.org/sici?sici=0012-9682\%28198407\%2952\%3A4\%3C909\%3AEMFCDW\%3E2.0.CO\%3B2-M

NOTE: The reference numbering from the original has been maintained in this citation list. 
http://www.jstor.org

\section{LINKED CITATIONS}

- Page 6 of 7 -

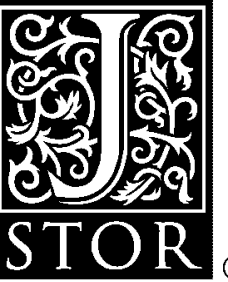

\section{Racing with Uncertainty}

Christopher Harris; John Vickers

The Review of Economic Studies, Vol. 54, No. 1. (Jan., 1987), pp. 1-21.

Stable URL:

http://links.jstor.org/sici?sici=0034-6527\%28198701\%2954\%3A1\%3C1\%3ARWU\%3E2.0.CO\%3B2-V

Underinvestment and Incompetence as Responses to Radical Innovation: Evidence from the Photolithographic Alignment Equipment Industry

Rebecca Henderson

The RAND Journal of Economics, Vol. 24, No. 2. (Summer, 1993), pp. 248-270.

Stable URL:

http://links.jstor.org/sici?sici=0741-6261\%28199322\%2924\%3A2\%3C248\%3AUAIART\%3E2.0.CO\%3B2-M

Technological Opportunity and Spillovers of R \& D: Evidence from Firms' Patents, Profits, and Market Value

Adam B. Jaffe

The American Economic Review, Vol. 76, No. 5. (Dec., 1986), pp. 984-1001.

Stable URL:

http://links.jstor.org/sici?sici=0002-8282\%28198612\%2976\%3A5\%3C984\%3ATOASOR\%3E2.0.CO\%3B2-M

\section{Some ARMA Models for Dependent Sequences of Poisson Counts}

Ed McKenzie

Advances in Applied Probability, Vol. 20, No. 4. (Dec., 1988), pp. 822-835.

Stable URL:

http://links.jstor.org/sici?sici=0001-8678\%28198812\%2920\%3A4\%3C822\%3ASAMFDS\%3E2.0.CO\%3B2-M

On Patents, R \& D, and the Stock Market Rate of Return

Ariel Pakes

The Journal of Political Economy, Vol. 93, No. 2. (Apr., 1985), pp. 390-409.

Stable URL:

http://links.jstor.org/sici?sici=0022-3808\%28198504\%2993\%3A2\%3C390\%3AOPR\%26DA\%3E2.0.CO\%3B2-1

Patents as Options: Some Estimates of the Value of Holding European Patent Stocks

Ariel Pakes

Econometrica, Vol. 54, No. 4. (Jul., 1986), pp. 755-784.

Stable URL:

http://links.jstor.org/sici?sici=0012-9682\%28198607\%2954\%3A4\%3C755\%3APAOSEO\%3E2.0.CO\%3B2-X

NOTE: The reference numbering from the original has been maintained in this citation list. 
http://www.jstor.org

\section{LINKED CITATIONS \\ - Page 7 of 7 -}

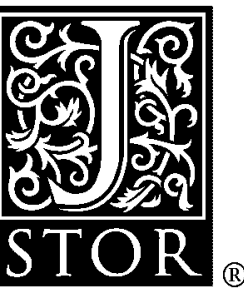

The Size Distribution of Innovating Firms in the UK: 1945-1983

K. Pavitt; M. Robson; J. Townsend

The Journal of Industrial Economics, Vol. 35, No. 3. (Mar., 1987), pp. 297-316.

Stable URL:

http://links.jstor.org/sici?sici=0022-1821\%28198703\%2935\%3A3\%3C297\%3ATSDOIF\%3E2.0.CO\%3B2-U

A Generalized $\mathbf{R}^{\wedge} 2$ Criterion for Regression Models Estimated by the Instrumental Variables Method

M. Hashem Pesaran; Richard J. Smith

Econometrica, Vol. 62, No. 3. (May, 1994), pp. 705-710.

Stable URL:

http://links.jstor.org/sici?sici=0012-9682\%28199405\%2962\%3A3\%3C705\%3AAGRCFR\%3E2.0.CO\%3B2-H

Uncertain Innovation and the Persistence of Monopoly

Jennifer F. Reinganum

The American Economic Review, Vol. 73, No. 4. (Sep., 1983), pp. 741-748.

Stable URL:

http://links.jstor.org/sici?sici=0002-8282\%28198309\%2973\%3A4\%3C741\%3AUIATPO\%3E2.0.CO\%3B2-H

Market Structure and the Employment of Scientists and Engineers

F. M. Scherer

The American Economic Review, Vol. 57, No. 3. (Jun., 1967), pp. 524-531.

Stable URL:

http://links.jstor.org/sici?sici=0002-8282\%28196706\%2957\%3A3\%3C524\%3AMSATEO\%3E2.0.CO\%3B2-D

NOTE: The reference numbering from the original has been maintained in this citation list. 